Check for updates

Cite this: RSC Adv., 2018, 8, 39902

Received 21st September 2018 Accepted 20th November 2018

DOI: $10.1039 / \mathrm{c} 8 \mathrm{ra07863g}$

rsc.li/rsc-advances

\section{Enhanced performance of chemical looping combustion of methane with $\mathrm{Fe}_{2} \mathrm{O}_{3} / \mathrm{Al}_{2} \mathrm{O}_{3} / \mathrm{TiO}_{2}$ oxygen carrier}

\begin{abstract}
Hsuan-Chih Wu (D) and Young Ku*
Iron-based oxygen carriers supported on alumina or alumina/titania were prepared and evaluated for chemical looping combustion of methane. The reduction conversion of $\mathrm{Fe}_{2} \mathrm{O}_{3} / \mathrm{Al}_{2} \mathrm{O}_{3}$ and $\mathrm{Fe}_{2} \mathrm{O}_{3} / \mathrm{Al}_{2} \mathrm{O}_{3} /$ $\mathrm{TiO}_{2}$ particles was markedly increased with increasing inlet concentration and was slightly enhanced by elevated operating temperatures. According to the shrinking core model, the mass transfer coefficients $\left(k_{\mathrm{g}}\right)$ of $\mathrm{Fe}_{2} \mathrm{O}_{3} / \mathrm{Al}_{2} \mathrm{O}_{3}$ and $\mathrm{Fe}_{2} \mathrm{O}_{3} / \mathrm{Al}_{2} \mathrm{O}_{3} / \mathrm{TiO}_{2}$ reduction with methane are found to be 0.07 and $0.12 \mathrm{~mm}$ $\mathrm{s}^{-1}$. Complete combustion of methane is almost achieved for experiments conducted with $\mathrm{Fe}_{2} \mathrm{O}_{3} / \mathrm{Al}_{2} \mathrm{O}_{3}$ and $\mathrm{Fe}_{2} \mathrm{O}_{3} / \mathrm{Al}_{2} \mathrm{O}_{3} / \mathrm{TiO}_{2}$ operated as the $\mathrm{Fe}_{2} \mathrm{O}_{3} / \mathrm{CH}_{4}$ molar ratio reached about 5.4 and 4.4 , respectively. Carbon deposition during methane combustion was avoided by using $\mathrm{Fe}_{2} \mathrm{O}_{3} / \mathrm{Al}_{2} \mathrm{O}_{3} / \mathrm{TiO}_{2}$ as an oxygen carrier. More heat was generated for the combustion of methane by $\mathrm{Fe}_{2} \mathrm{O}_{3} / \mathrm{Al}_{2} \mathrm{O}_{3} / \mathrm{TiO}_{2}$ oxygen carriers because methane more fully reacted with the $\mathrm{Fe}_{2} \mathrm{O}_{3}$ contained in the $\mathrm{Fe}_{2} \mathrm{O}_{3} / \mathrm{Al}_{2} \mathrm{O}_{3} / \mathrm{TiO}_{2}$ oxygen carriers.
\end{abstract}

\section{Introduction}

Shale gas is an important natural gas resource, and distributed in many countries, such as China, Argentina, Algeria, U.S., Canada, Mexico, Australia, South Africa, and Russia etc. ${ }^{1}$ For U.S. dry natural gas production, shale gas as the largest contributor has rapidly grown by $40 \%$ from 9.7 trillion cubic feet in 2012 to 13.6 trillion cubic feet in $2015 .^{2,3}$ Natural gas is one of the primary fuels composed of approximately $90 \%$ of methane, which is widely used as a fuel and chemical feedstock for the conversion of methane to generate a number of products, for instance, hydrogen, liquid fuels, chemicals, heat, and electricity. ${ }^{4}$ However, carbon dioxide $\left(\mathrm{CO}_{2}\right)$ is also generated during a variety of methane conversion processes. $\mathrm{CO}_{2}$ is a major contributor to global warming and climate change. In order to combat global warming and mitigate the $\mathrm{CO}_{2}$ emissions, various carbon capture, storage, and utilization technologies have recently been developed.

Chemical looping process (CLP) is considered to be a novel alternative for fuel combustion to achieve efficient energy generation as well as inherent $\mathrm{CO}_{2}$ separation. A chemical looping system is typically comprised of a fuel reactor and an air reactor. Carbonaceous fuels are oxidized by metal oxides (oxygen carriers) in the fuel reactor to generate $\mathrm{CO}_{2}$ and $\mathrm{H}_{2} \mathrm{O}$. The reduced oxygen carrier is subsequently oxidized and regenerated by air in the air reactor.

The performance of the oxygen carrier is crucial for CLP development and is greatly influenced by the characteristics of

Department of Chemical Engineering, National Taiwan University of Science and Technology, Taipei 10607, Taiwan.E-mail: ku508@mail.ntust.edu.tw metal oxide and support material. Fe-based oxygen carriers are frequently applied for chemical looping combustion of gaseous fuel; however, sintering and attrition during continuous and high-temperature operations would decrease the reactivity of these oxygen carriers. Therefore, oxygen carriers of mixed metal oxide and support material are frequently employed for chemical looping operations to retard the sintering of oxygen carriers and to enhance their mechanical strength. ${ }^{5}$ Adánez et al. ${ }^{6}$ studied the CLC of methane in a thermogravimetric analyzer (TGA) using hematite as active phase and supported by various inert materials, and also reported that $\mathrm{Fe}_{2} \mathrm{O}_{3} / \mathrm{Al}_{2} \mathrm{O}_{3}$ and $\mathrm{Fe}_{2} \mathrm{O}_{3} /$ $\mathrm{ZrO}_{2}$ oxygen carriers containing $40-80 \mathrm{wt} \% \mathrm{Fe}_{2} \mathrm{O}_{3}$ sintered at above $1100{ }^{\circ} \mathrm{C}$ exhibited high reactivity with methane and delivered high crush strength. Johansson et al. ${ }^{7}$ utilized the $\mathrm{Fe}_{2} \mathrm{O}_{3}$ supported with $\mathrm{MgAl}_{2} \mathrm{O}_{4}$ as an oxygen carrier to investigate their reactivity properties on the CLC of methane in a fluidized bed reactor. The results indicated that $60 \mathrm{wt} \% \mathrm{Fe}_{2} \mathrm{O}_{3} /$ $\mathrm{MgAl}_{2} \mathrm{O}_{4}$ oxygen carriers sintered at $1100^{\circ} \mathrm{C}$ demonstrated high reactivity regarding methane combustion. In addition, the crush strength of $\mathrm{Fe}_{2} \mathrm{O}_{3} / \mathrm{MgAl}_{2} \mathrm{O}_{4}$ particles ranged of 125 to 180 $\mu \mathrm{m}$ was determined to be about $1.8 \mathrm{~N}$. Zafar $e t$ al. ${ }^{8}$ investigated $\mathrm{Fe}_{2} \mathrm{O}_{3}$ on the $\mathrm{MgAl}_{2} \mathrm{O}_{4}$ and $\mathrm{SiO}_{2}$ supports in a fluidized bed reactor for CLC application, and found that the $\mathrm{Fe}_{2} \mathrm{O}_{3} / \mathrm{MgAl}_{2} \mathrm{O}_{4}$ oxygen carriers showed high reactivity with methane during the $\mathrm{Fe}_{2} \mathrm{O}_{3}$ reduced to $\mathrm{Fe}_{3} \mathrm{O}_{4}$, whereas the poor reactivity with methane was observed during the $\mathrm{Fe}_{3} \mathrm{O}_{4}$ reduced to $\mathrm{FeO}$. Besides, the unreactive iron silicate was formed at high temperature by using $\mathrm{SiO}_{2}$ as support. Corbella and Palacios ${ }^{9}$ revealed the methane conversion was reached about $90 \%$ for methane combustion with titania supported $\mathrm{Fe}_{2} \mathrm{O}_{3}$ oxygen carriers in a fixed bed reactor operated at $900{ }^{\circ} \mathrm{C}$, and also 
reported that the low oxygen capacity was caused in the reduction stage because the interaction between ironcontaining active phase and the support material lead to the formation of an irreducible phase $\mathrm{FeTiO}_{3}$. Li et al. ${ }^{\mathbf{1 0}}$ indicated $\mathrm{TiO}_{2}$ as support can markedly lower the energy barrier for $\mathrm{O}^{2-}$ migration within the dense solid phase, thus enhancing the $\mathrm{O}^{2-}$ diffusivity. ${ }^{10}$ Qin et al. ${ }^{11}$ stated the vacancy defect is easy to form on the $\mathrm{FeTiO}_{3}$ surface because the vacancy formation energy of $\mathrm{FeTiO}_{3}$ is lower than $\mathrm{Fe}_{2} \mathrm{O}_{3}$ in the reduction stage. Consequently, the enhancing the porous surface structure formation on $\mathrm{FeTiO}_{3}$. However, Zhao and Shadman ${ }^{12}$ observed that phase separation of iron oxide phase and titania phase during the redox cycles. Iron oxide migrates to the surface of $\mathrm{FeTiO}_{3}$ during the oxidation, which could fracture the ilmenite particle. This mechanism might lower the particle strength.

In this study, alumina is selected as support to improve the mechanical strength of iron-based oxygen carrier, and titania is employed as another support to promote the reactivity. Based our previous research results, the components of the $\mathrm{Fe}_{2} \mathrm{O}_{3}$ / $\mathrm{Al}_{2} \mathrm{O}_{3}$ and $\mathrm{Fe}_{2} \mathrm{O}_{3} / \mathrm{Al}_{2} \mathrm{O}_{3} / \mathrm{TiO}_{2}$ oxygen carriers were optimized to achieve the better reactivity during TGA tests and mechanical strength. ${ }^{\mathbf{1 3 , 1 4}}$ The optimized composition of $\mathrm{Fe}_{2} \mathrm{O}_{3} / \mathrm{Al}_{2} \mathrm{O}_{3}$ and $\mathrm{Fe}_{2} \mathrm{O}_{3} / \mathrm{Al}_{2} \mathrm{O}_{3} / \mathrm{TiO}_{2}$ oxygen carriers were determined to be $60 / 40$ and 70/20/10 in weight percentage. Alumina and alumina/ titania supported $\mathrm{Fe}_{2} \mathrm{O}_{3}$ oxygen carriers $\left(\mathrm{Fe}_{2} \mathrm{O}_{3} / \mathrm{Al}_{2} \mathrm{O}_{3}\right.$ and $\mathrm{Fe}_{2} \mathrm{O}_{3} / \mathrm{Al}_{2} \mathrm{O}_{3} / \mathrm{TiO}_{2}$ ) were fabricated to investigate their reactivity properties in a fixed bed reactor. The effect of operating temperature and inlet gas concentration on the combustion of $\mathrm{CH}_{4}$ with $\mathrm{Fe}_{2} \mathrm{O}_{3} / \mathrm{Al}_{2} \mathrm{O}_{3}$ and $\mathrm{Fe}_{2} \mathrm{O}_{3} / \mathrm{Al}_{2} \mathrm{O}_{3} / \mathrm{TiO}_{2}$ oxygen carriers in a fixed bed reactor was examined and analyzed by shrinking core model (SCM). Preliminarily kinetic study for CLC of methane with $\mathrm{Fe}_{2} \mathrm{O}_{3} / \mathrm{Al}_{2} \mathrm{O}_{3}$ and $\mathrm{Fe}_{2} \mathrm{O}_{3} / \mathrm{Al}_{2} \mathrm{O}_{3} / \mathrm{TiO}_{2}$ oxygen carriers are performed based on the experimental results from this study. Furthermore, the performance of the moving bed reactor using iron-based oxygen carriers was also discussed in this study. $\mathrm{Fe}_{2} \mathrm{O}_{3} / \mathrm{Al}_{2} \mathrm{O}_{3}$ and $\mathrm{Fe}_{2} \mathrm{O}_{3} / \mathrm{Al}_{2} \mathrm{O}_{3} / \mathrm{TiO}_{2}$ oxygen carriers were employed for chemical looping combustion of methane in a moving bed reactor (MBR) operated with the various $\mathrm{CH}_{4}$ / $\mathrm{Fe}_{2} \mathrm{O}_{3}$ ratio. The methane conversion, carbon conversion, and oxygen carrier conversion for methane combustion by $\mathrm{Fe}_{2} \mathrm{O}_{3}$ / $\mathrm{Al}_{2} \mathrm{O}_{3}$ and $\mathrm{Fe}_{2} \mathrm{O}_{3} / \mathrm{Al}_{2} \mathrm{O}_{3} / \mathrm{TiO}_{2}$ oxygen carriers were evaluated by the moving bed reactor. The crystalline phases of the reduced oxygen carrier after the moving bed operation were identified by $\mathrm{X}$-ray diffraction (XRD). Heat analysis for chemical looping combustion of methane was employed to evaluate the heat balance of input and output processing capacities.

\section{Experimental}

\subsection{Preparation of various iron-based oxygen carriers}

$\mathrm{Fe}_{2} \mathrm{O}_{3} / \mathrm{Al}_{2} \mathrm{O}_{3}$ and $\mathrm{Fe}_{2} \mathrm{O}_{3} / \mathrm{Al}_{2} \mathrm{O}_{3} / \mathrm{TiO}_{2}$ particles were prepared to serve as oxygen carriers in this study. $\mathrm{Fe}_{2} \mathrm{O}_{3} / \mathrm{Al}_{2} \mathrm{O}_{3}$ oxygen carriers were formulated with $60 \mathrm{wt} \%$ hematite $\left(99.9 \% \mathrm{Fe}_{2} \mathrm{O}_{3}\right.$, China Steel) and $40 \mathrm{wt} \%$ alumina (99\% $\mathrm{Al}_{2} \mathrm{O}_{3}$, Chin Jung). $\mathrm{Fe}_{2} \mathrm{O}_{3} / \mathrm{Al}_{2} \mathrm{O}_{3} / \mathrm{TiO}_{2}$ were formulated with $70 \mathrm{wt} \%$ hematite, $20 \mathrm{wt} \%$ alumina and $10 \mathrm{wt} \%$ titania. Hematite, alumina and titania particles of roughly $1 \mu \mathrm{m}$ were mixed in deionized water and dried at $80{ }^{\circ} \mathrm{C}$ for 6 hours to form a cake, and were then pulverized and screened for sizes between 1.2 and $1.4 \mathrm{~mm}$. The $\mathrm{Fe}_{2} \mathrm{O}_{3} / \mathrm{Al}_{2} \mathrm{O}_{3}$ and $\mathrm{Fe}_{2} \mathrm{O}_{3} / \mathrm{Al}_{2} \mathrm{O}_{3} / \mathrm{TiO}_{2}$ particles were later sintered at $1300{ }^{\circ} \mathrm{C}$ and $1200{ }^{\circ} \mathrm{C}$ for 2 hours in a muffle furnace, respectively. The crush strength of prepared oxygen carriers was analyzed by a texture machine (TA.XT plus), and the attrition of prepared oxygen carriers was examined by an attrition analyzer following ASTM methods D4058-96. The true density, particle density and bulk density of prepared oxygen carriers were determined by eqn (1) and (2), respectively, similar defines and results were reported by previous researchers. ${ }^{15}$

$$
\begin{aligned}
& \rho_{\mathrm{p}}=(1-\phi) \rho_{\mathrm{t}} \\
& \rho_{\mathrm{b}}=(1-\varepsilon) \rho_{\mathrm{p}}
\end{aligned}
$$

where $\rho_{\mathrm{t}}$ is the true density of the oxygen carrier without the pores which presented in the oxygen carrier; $\rho_{\mathrm{p}}$ is the particle density of the oxygen carrier including the pores, which was measured by the Archimedes method; is the bulk density of the oxygen carrier; $\phi$ is $49.13 \%$ and $59.60 \%$ as the porosity of prepared $\mathrm{Fe}_{2} \mathrm{O}_{3} / \mathrm{Al}_{2} \mathrm{O}_{3}$ and $\mathrm{Fe}_{2} \mathrm{O}_{3} / \mathrm{Al}_{2} \mathrm{O}_{3} / \mathrm{TiO}_{2}$, respectively; $\varepsilon$ is the fraction of void contained in the packed $\mathrm{Fe}_{2} \mathrm{O}_{3} / \mathrm{Al}_{2} \mathrm{O}_{3}$ and $\mathrm{Fe}_{2} \mathrm{O}_{3} / \mathrm{Al}_{2} \mathrm{O}_{3} / \mathrm{TiO}_{2}$ oxygen carriers, which were determined to be $41.61 \%$ and $40.17 \%$, respectively. The main physicochemical properties of these prepared iron-based oxygen carriers are shown in Table 1.

A porosity of fresh oxygen carriers was measured by Archimedes method in water. The porosities of $\mathrm{Fe}_{2} \mathrm{O}_{3} / \mathrm{Al}_{2} \mathrm{O}_{3}$ and $\mathrm{Fe}_{2} \mathrm{O}_{3} / \mathrm{Al}_{2} \mathrm{O}_{3} / \mathrm{TiO}_{2}$ oxygen carriers were determined to be $49.13 \%$ and $59.60 \%$, respectively. The physical properties of $60 \mathrm{wt} \%$ $\mathrm{Fe}_{2} \mathrm{O}_{3} / \mathrm{Al}_{2} \mathrm{O}_{3}$ oxygen carriers reported by De Vos et al. ${ }^{16}$ were similar to the results of this study that the porosity was obtained to be in the range of $49.10-59.70 \%{ }^{16}$ From the literature published by Breault et al. ${ }^{17}$ illustrated that the disappear of small grains due to the growth of larger grain promoted by hightemperature calcination, hence, the grain size and porosity become larger, while the specific surface area becomes smaller. ${ }^{17}$ Breault et al. ${ }^{17}$ also reported that as the calcination temperature is raised to $1000{ }^{\circ} \mathrm{C}$, the specific surface area of hematite particles was dropped from 6.0 to $0.3 \mathrm{~m}^{2} \mathrm{~g}^{-1} .^{17} \mathrm{~A}$ similar result was observed in this study, the specific surface area of $\mathrm{Fe}_{2} \mathrm{O}_{3} / \mathrm{Al}_{2} \mathrm{O}_{3}$ and $\mathrm{Fe}_{2} \mathrm{O}_{3} / \mathrm{Al}_{2} \mathrm{O}_{3} / \mathrm{TiO}_{2}$ oxygen carriers

Table 1 Main physicochemical properties of the iron-based oxygen carriers

\begin{tabular}{llll}
\hline Parameters & Unit & $\mathrm{Fe}_{2} \mathrm{O}_{3} / \mathrm{Al}_{2} \mathrm{O}_{3}$ & $\mathrm{Fe}_{2} \mathrm{O}_{3} / \mathrm{Al}_{2} \mathrm{O}_{3} / \mathrm{TiO}_{2}$ \\
\hline $\mathrm{Fe}_{2} \mathrm{O}_{3}$ fraction & $\mathrm{wt} \%$ & 60 & 70 \\
Particle size & $\mathrm{mm}$ & $1.2-1.4$ & $1.2-1.4$ \\
True density, $\rho_{\mathrm{t}}$ & $\mathrm{kg} \mathrm{m}^{-3}$ & 4673 & 4795 \\
Particle density, $\rho_{\mathrm{p}}$ & $\mathrm{kg} \mathrm{m}^{-3}$ & 2377 & 1937 \\
Bulk density, $\rho_{\mathrm{b}}$ & $\mathrm{kg} \mathrm{m}^{-3}$ & 1388 & 1159 \\
Porosity & $\%$ & 49.13 & 59.60 \\
Fraction void & $\%$ & 41.61 & 40.17 \\
Crushing strength & $\mathrm{N}$ & 30.53 & 10.25 \\
Attrition & $\%$ & 4.01 & 16.83 \\
Specific surface area, BET & $\mathrm{m}^{2} \mathrm{~g}^{-1}$ & 0.61 & 0.64
\end{tabular}


determined by BET analysis were 0.61 and $0.64 \mathrm{~m}^{2} \mathrm{~g}^{-1}$ at calcination temperatures of $1300{ }^{\circ} \mathrm{C}$ and $1100{ }^{\circ} \mathrm{C}$, respectively.

\subsection{Establishment of the fixed bed reactor system}

A fixed-bed reactor system composed of a $25.4 \mathrm{~mm}$ ID SS310 reactor and with a PID-controlled heating element covering $200 \mathrm{~mm}$ of reactor length employed in this study is shown in Fig. 1. A plate with sixteen $0.25 \mathrm{~mm}$ apertures was located in the lower part of the reactor for supporting $40 \mathrm{~g}$ of prepared $\mathrm{Fe}_{2} \mathrm{O}_{3} /$ $\mathrm{Al}_{2} \mathrm{O}_{3}$ particles or $30.2 \mathrm{~g}$ of prepared $\mathrm{Fe}_{2} \mathrm{O}_{3} / \mathrm{Al}_{2} \mathrm{O}_{3} / \mathrm{TiO}_{2}$ particles. The temperature of the loaded reactor was then increased from room temperature with a ramping rate of $10{ }^{\circ} \mathrm{C} \mathrm{min}^{-1}$ and eventually kept at a specific operating temperature, ranging from 875 to $925{ }^{\circ} \mathrm{C}$. For reduction experiments, methane was introducing into the reactor at a flow rate of $1 \mathrm{~L} \mathrm{~min}^{-1}$ at different concentrations, ranging from 5 to $20 \%$. After reduction, $\mathrm{N}_{2}$ was introduced for sweeping reducing gas contained in the reactor. Air at a flow rate of $1 \mathrm{~L} \mathrm{~min}^{-1}$ was subsequently introduced for 30 minutes to oxidize the reduced oxygen carriers. The outlet stream from the reactor was passed through a cold trap to condense steam, and was consequently analyzed by a non-dispersive infrared sensor (NDIR, Molecular Analysis 6000i) and a gas chromatography equipped with a thermal conductivity detector (GC-TCD, China Chromatography 2000) to detect the concentrations of carbon dioxide, carbon monoxide, methane, hydrogen, and oxygen.

\subsection{Establishment of the moving bed reactor system}

Schematic diagram of the annular duel-tube moving bed reactor (ADMBR) employed in this study is shown in Fig. 2. The reactor was composed of a $76.20 \mathrm{~mm}$ ID SS310S outer tube covered with an electric heating element to provide isothermally atmosphere, and a $25.40 \mathrm{~mm}$ ID SS310S inner tube. Roughly $3.0 \mathrm{~kg}$ of prepared $\mathrm{Fe}_{2} \mathrm{O}_{3} / \mathrm{Al}_{2} \mathrm{O}_{3}$ oxygen carriers or $2.5 \mathrm{~kg}$ of prepared $\mathrm{Fe}_{2} \mathrm{O}_{3} / \mathrm{Al}_{2} \mathrm{O}_{3} / \mathrm{TiO}_{2}$ oxygen carriers were initially packed in the spacing between inner and outer tubes of the ADMBR. $\mathrm{Fe}_{2} \mathrm{O}_{3} /$ $\mathrm{Al}_{2} \mathrm{O}_{3}$ and $\mathrm{Fe}_{2} \mathrm{O}_{3} / \mathrm{Al}_{2} \mathrm{O}_{3} / \mathrm{TiO}_{2}$ oxygen carriers were then continuously fed into the packed reactor by a screw conveyor at flow rate operated at 29.53 and $20.72 \mathrm{~g} \mathrm{~min}^{-1}$, respectively. Methane was fed into inner tube to serve as gaseous fuel, and $\mathrm{N}_{2}$ was also introduced into the inner tube at a flow rate of $2.2 \mathrm{~L} \mathrm{~min}^{-1}$. The fuel gas was then passing through the bottom of the inner tube

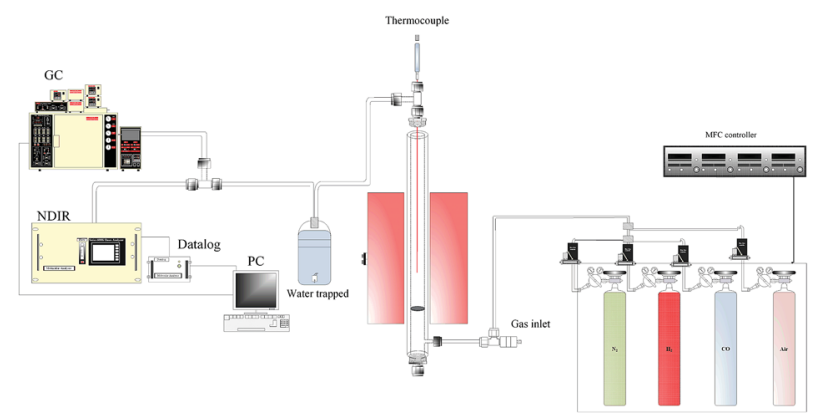

Fig. 1 Schematic diagram of the fixed bed reactor system used in this study for CLP operation.

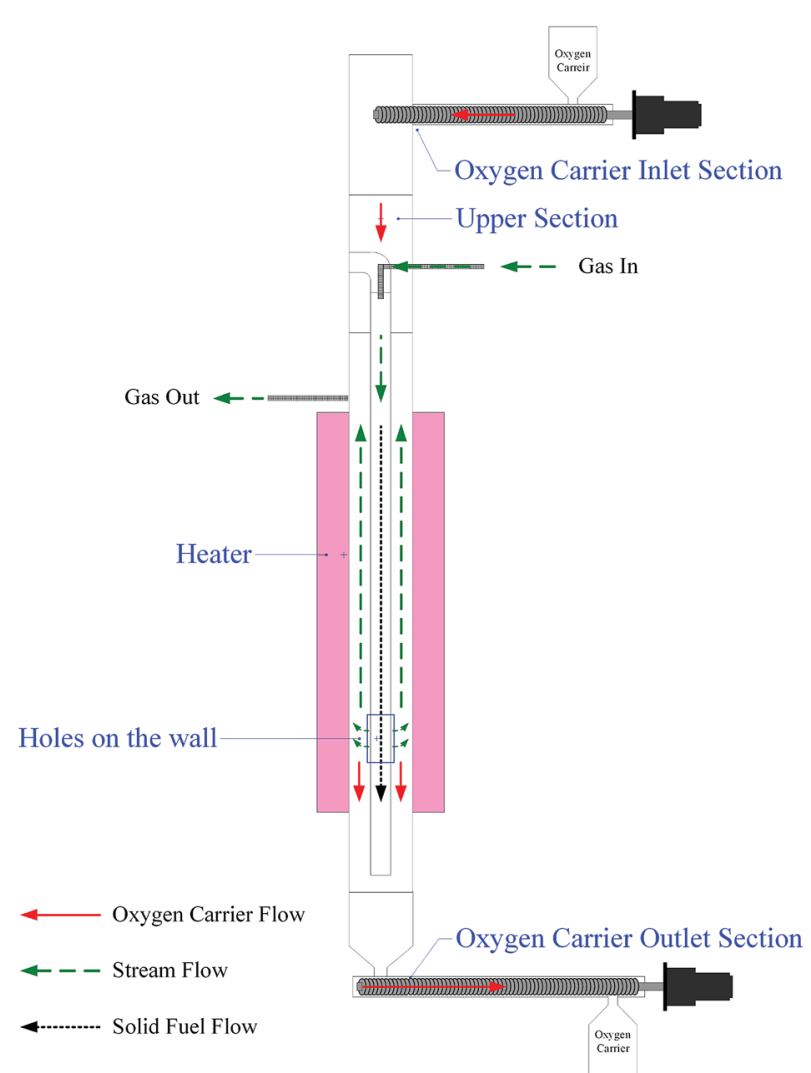

Fig. 2 Schematic diagram of the moving bed reactor system used in this study for methane combustion.

for consequent combustion with Fe-based oxygen carriers fed into and moved through the moving bed reactor. The reduced oxygen carriers were collectively removed out of the fuel reactor by another screw conveyor. The outlet stream from the moving bed reactor was cooled by a cold trap to condense water vapour and was afterward analyzed by a gas chromatography equipped with a thermal conductivity detector (GC-TCD, China Chromatography 2000) to detect the concentration of $\mathrm{H}_{2}$ and a nondispersive infrared sensor (NDIR, Molecular Analysis 6000i) to detect the concentration of $\mathrm{CO}_{2}, \mathrm{CO}, \mathrm{CH}_{4}$, and $\mathrm{O}_{2}$. The phase transformation of prepared oxygen carriers during methane combustion was characterized by X-ray diffraction (XRD).

\section{Results and discussion}

3.1 Methane combustion with iron-based oxygen carriers in a fixed bed reactor

Moving bed reactor (MBR) with counter-flow for solids and gases were proposed to enhance the utilization of available oxygen in the oxygen carriers. ${ }^{18}$ In order to estimate the influence of thermal and chemical effects only on the oxygen carrier reduction, a fixed bed reactor was used instead of moving beds. Indeed, the fixed bed allows avoiding any flow of the material, and the performance of the oxygen carrier in this kind of reactor may only be the consequence of chemical and thermal effects. The reactivity of prepared $\mathrm{Fe}_{2} \mathrm{O}_{3} / \mathrm{Al}_{2} \mathrm{O}_{3}$ and $\mathrm{Fe}_{2} \mathrm{O}_{3} / \mathrm{Al}_{2} \mathrm{O}_{3} / \mathrm{TiO}_{2}$ oxygen carriers were investigated and conducted in the fixed 
bed reactor operated at the temperature between 875 and $925{ }^{\circ} \mathrm{C}$ by feeding $\mathrm{CH}_{4} / \mathrm{N}_{2}$ gas mixtures containing 5 to $20 \mathrm{vol} \% \mathrm{CH}_{4}$. The iron-based oxygen carriers are fully reduced for methane combustion as described by reaction (3)..$^{\mathbf{4 , 1 9 , 2 0}}$

$$
\mathrm{CH}_{4}+\frac{4}{3} \mathrm{Fe}_{2} \mathrm{O}_{3} \leftrightarrow \frac{8}{3} \mathrm{Fe}+\mathrm{CO}_{2}+2 \mathrm{H}_{2} \mathrm{O}
$$

Based on the mass balances of oxygen and hydrogen, the reduction conversion of iron-based oxygen carriers for methane combustion is determined as:

$$
\begin{aligned}
X_{\text {red }} & =\frac{\int\left(2 F_{\mathrm{CO}_{2}}+F_{\mathrm{CO}}+F_{\mathrm{H}_{2} \mathrm{O}}\right) \mathrm{d} t}{\left(\frac{x_{\mathrm{Fe}_{2} \mathrm{O}_{3}} \cdot m_{\mathrm{OC}}}{M_{\mathrm{Fe}_{2} \mathrm{O}_{3}}}\right)} \\
F_{\mathrm{H}_{2} \mathrm{O}} & =2 F_{\mathrm{CH}_{4} \text { in }}-\left(2 F_{\mathrm{CH}_{4}}+F_{\mathrm{H}_{2}}\right)
\end{aligned}
$$

where $F_{\mathrm{CH}_{4}, \text { in }}$ is the inlet mole flow rate $\left(\mathrm{mmol} \mathrm{min}^{-1}\right)$ of $\mathrm{CH}_{4} ; F_{\mathrm{i}}$ is the outlet molar flow rate $\left(\mathrm{mmol} \mathrm{min}^{-1}\right)$ of species $\mathrm{i}$, i is denoted as $\mathrm{CO}_{2}, \mathrm{CO}, \mathrm{H}_{2} \mathrm{O}, \mathrm{H}_{2}$, and $\mathrm{CH}_{4} ; m_{\mathrm{OC}}$ is the weight (g) of oxygen carriers packed in the reactor; $x_{\mathrm{Fe}_{2} \mathrm{O}_{3}}$ is the fraction of $\mathrm{Fe}_{2} \mathrm{O}_{3}$ contained in the oxygen carriers; $M_{\mathrm{Fe}_{2} \mathrm{O}_{3}}$ is $159.69 \mathrm{~g} \mathrm{~mol}^{-1}$ as the molecular weight of $\mathrm{Fe}_{2} \mathrm{O}_{3}$. Fig. 3 shows the effect of operating temperature on the reduction of iron-based oxygen carriers with methane. The reduction conversions of $\mathrm{Fe}_{2} \mathrm{O}_{3}$ / $\mathrm{Al}_{2} \mathrm{O}_{3} / \mathrm{TiO}_{2}$ oxygen carriers calculated for experiments conducted with constant operation time are significantly higher than that of $\mathrm{Fe}_{2} \mathrm{O}_{3} / \mathrm{Al}_{2} \mathrm{O}_{3}$ oxygen carriers and are increased with higher operating temperatures. For instance, more than 95\% $\mathrm{Fe}_{2} \mathrm{O}_{3} / \mathrm{Al}_{2} \mathrm{O}_{3} / \mathrm{TiO}_{2}$ is reduced by methane at about 84 minutes for experiments conducted at $925^{\circ} \mathrm{C}$, much higher than that for $\mathrm{Fe}_{2} \mathrm{O}_{3} / \mathrm{Al}_{2} \mathrm{O}_{3}$ reduction with methane. Fig. 4 demonstrates the effect of inlet methane concentrations on the CLC of $\mathrm{CH}_{4}$ by iron-based oxygen carriers. The conversions of $\mathrm{Fe}_{2} \mathrm{O}_{3} / \mathrm{Al}_{2} \mathrm{O}_{3}$ and $\mathrm{Fe}_{2} \mathrm{O}_{3} / \mathrm{Al}_{2} \mathrm{O}_{3} / \mathrm{TiO}_{2}$ reduction are increased for experiments conducted with greater inlet methane concentrations, possibly because of the existence of more methane molecules. More methane molecules are more ready to react with $\mathrm{Fe}_{2} \mathrm{O}_{3}$

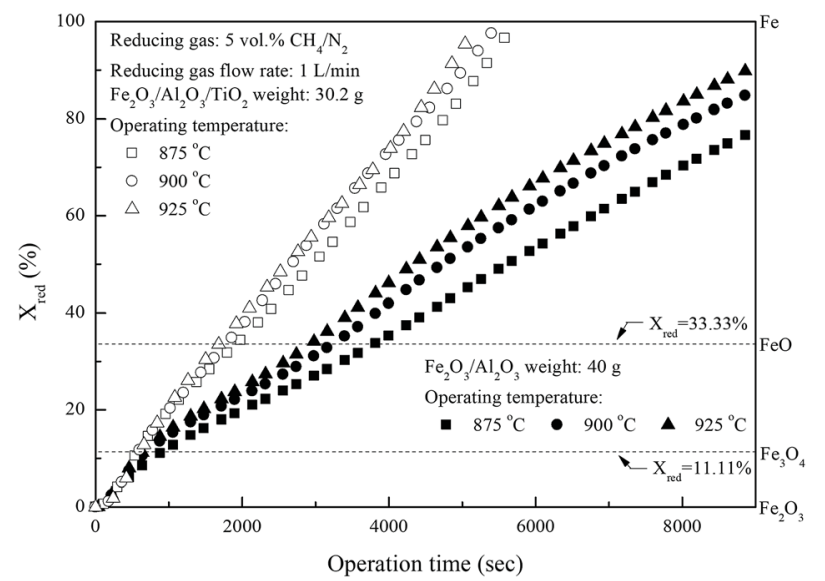

Fig. 3 Effect of operating temperature on the reduction of $\mathrm{Fe}_{2} \mathrm{O}_{3} /$ $\mathrm{Al}_{2} \mathrm{O}_{3}$ and $\mathrm{Fe}_{2} \mathrm{O}_{3} / \mathrm{Al}_{2} \mathrm{O}_{3} / \mathrm{TiO}_{2}$ with $\mathrm{CH}_{4}$ in the fixed bed.

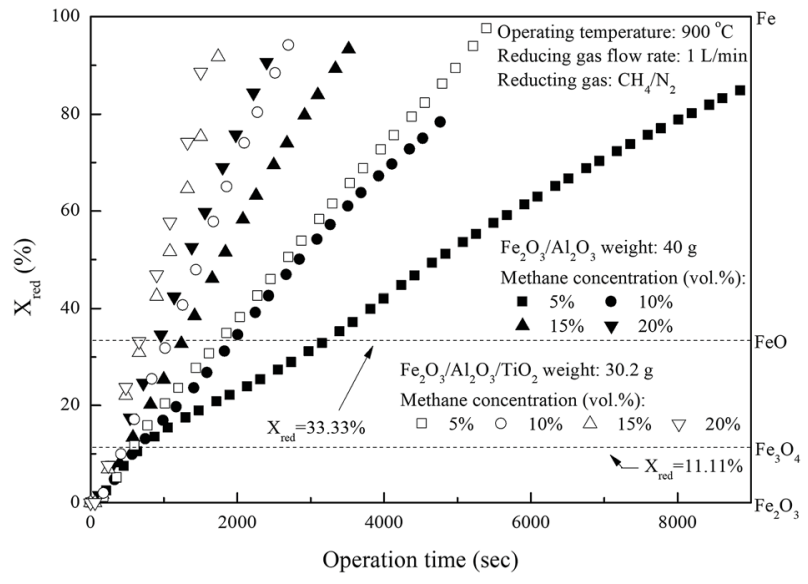

Fig. 4 Effect of inlet $\mathrm{CH}_{4}$ concentrations on the reduction of $\mathrm{Fe}_{2} \mathrm{O}_{3} /$ $\mathrm{Al}_{2} \mathrm{O}_{3}$ and $\mathrm{Fe}_{2} \mathrm{O}_{3} / \mathrm{Al}_{2} \mathrm{O}_{3} / \mathrm{TiO}_{2}$ with $\mathrm{CH}_{4}$ in the fixed bed.

contained in the iron-based oxygen carriers to generate $\mathrm{CO}_{2}$ and $\mathrm{H}_{2} \mathrm{O}$, as described by reaction (3).

In this study, the temporal behaviour of iron-based oxygen carrier reduction for methane combustion is described by a shrinking core model (SCM), as exercised by most researchers for the application of various oxygen carriers for chemical looping: ${ }^{21-23}$

$$
\begin{gathered}
1-X_{\text {red }}=\left(\frac{r}{R}\right)^{3} \\
t=\tau_{\mathrm{gf}} X_{\text {red }}+\tau_{\mathrm{pl}}\left[1-3\left(1-X_{\mathrm{red}}\right)^{\frac{2}{3}}+2\left(1-X_{\mathrm{red}}\right)\right] \\
\tau_{\mathrm{gf}}=\frac{1000 x_{\mathrm{Fe}_{2} \mathrm{O}_{3}} \rho_{\mathrm{P}} R}{3 b C_{\mathrm{Ag}_{\mathrm{g}} M_{\mathrm{Fe}_{2} \mathrm{O}_{3}} k_{\mathrm{g}}}} \\
\tau_{\mathrm{pl}}=\frac{1000 x_{\mathrm{Fe}_{2} \mathrm{O}_{3}} \rho_{\mathrm{P}} R^{2}}{6 b C_{\mathrm{Ag}_{\mathrm{g}} M_{\mathrm{Fe}_{2} \mathrm{O}_{3}} D_{\mathrm{e}}}} \\
D_{\mathrm{e}}=D_{\mathrm{pl}, 0} \mathrm{e}^{-\frac{\mathrm{Ea}_{\mathrm{pl}}}{R_{\mathrm{g}} T}-k_{\mathrm{d}} X_{\mathrm{red}}} \\
k_{\mathrm{d}}=k_{\mathrm{d}, 0} \mathrm{e}^{-\frac{\mathrm{Ea}_{\mathrm{d}}}{R_{\mathrm{g}} T}}
\end{gathered}
$$

where $R$ and $r$ are the radius (m) of the fresh particle and the unreacted core; $\tau_{\mathrm{gf}}$ and $\tau_{\mathrm{pl}}$ are the time (s) required for complete conversion of the oxygen carrier when the reaction is controlled by the gas-film diffusion and the product layer diffusion; $C_{\mathrm{Ag}}$ is the inlet molar concentration $\left(\mathrm{mol} \mathrm{m}^{-3}\right)$ of the gaseous fuel; $b$ is the stoichiometric coefficient of gaseous fuel combusted with $\mathrm{Fe}_{2} \mathrm{O}_{3}$, which is determined to be $4 / 3$ by reaction (3); $k_{\mathrm{g}}$ is the mass transfer coefficient $\left(\mathrm{m} \mathrm{s}^{-1}\right)$ between gaseous fuel and oxygen carriers; $D_{\mathrm{e}}$ is the effective diffusion coefficient $\left(\mathrm{m}^{2} \mathrm{~s}^{-1}\right)$ of gaseous fuel in the product layer; $D_{\mathrm{pl}, 0}\left(\mathrm{~m}^{2} \mathrm{~s}^{-1}\right)$ and $\mathrm{Ea}_{\mathrm{pl}}(\mathrm{kJ}$ $\mathrm{mol}^{-1}$ ) are the pre-exponential factor and activation energy for the product layer diffusion reaction; $k_{\mathrm{d}}, k_{\mathrm{d}, 0}$ and $\mathrm{Ea}_{\mathrm{d}}\left(\mathrm{kJ} \mathrm{mol}^{-1}\right)$ are the decay constant, pre-exponential factor and activation energy for the product layer diffusivity; $R_{\mathrm{g}}$ is the ideal gas constant; $T(\mathrm{~K})$ is the operation temperature. 
The reduction kinetics of $\mathrm{Fe}_{2} \mathrm{O}_{3} / \mathrm{Al}_{2} \mathrm{O}_{3}$ and $\mathrm{Fe}_{2} \mathrm{O}_{3} / \mathrm{Al}_{2} \mathrm{O}_{3} / \mathrm{TiO}_{2}$ with methane are regressed and calculated by the shrinking core model (SCM), as described in eqn (6)-(11). After fitting the conversion curves, the kinetic parameters are summarized in Table 2. As listed in Table 2, the mass transfer coefficient $\left(k_{\mathrm{g}}\right)$ of around $0.07 \mathrm{~mm} \mathrm{~s}^{-1}$ is calculated for the reduction of $\mathrm{Fe}_{2} \mathrm{O}_{3} /$ $\mathrm{Al}_{2} \mathrm{O}_{3}$ with methane, while the $k_{\mathrm{g}}$ of $\mathrm{Fe}_{2} \mathrm{O}_{3} / \mathrm{Al}_{2} \mathrm{O}_{3} / \mathrm{TiO}_{2}$ for methane combustion reached $0.12 \mathrm{~mm} \mathrm{~s}^{-1}$, indicating that the reaction rate of methane for $\mathrm{Fe}_{2} \mathrm{O}_{3} / \mathrm{Al}_{2} \mathrm{O}_{3} / \mathrm{TiO}_{2}$ reduction is faster than that for $\mathrm{Fe}_{2} \mathrm{O}_{3} / \mathrm{Al}_{2} \mathrm{O}_{3}$ reduction. Less $D_{\mathrm{pl}, 0}$ is obtained for experiments with $\mathrm{Fe}_{2} \mathrm{O}_{3} / \mathrm{Al}_{2} \mathrm{O}_{3}$ oxygen carriers than those with $\mathrm{Fe}_{2} \mathrm{O}_{3} / \mathrm{Al}_{2} \mathrm{O}_{3} / \mathrm{TiO}_{2}$ oxygen carriers, explicitly, demonstrating that the methane more easily diffusion through the product layer of $\mathrm{Fe}_{2} \mathrm{O}_{3} / \mathrm{Al}_{2} \mathrm{O}_{3} / \mathrm{TiO}_{2}$ oxygen carriers. Moreover, the influence of operating temperature on the oxygen carrier conversions for the reduction of $\mathrm{Fe}_{2} \mathrm{O}_{3} / \mathrm{Al}_{2} \mathrm{O}_{3}$ with methane are more than that for $\mathrm{Fe}_{2} \mathrm{O}_{3} / \mathrm{Al}_{2} \mathrm{O}_{3} / \mathrm{TiO}_{2}$ reduction with methane, as shown in Fig. 3, because high activation energy for the product layer diffusion reaction $\left(\mathrm{Ea}_{\mathrm{pl}}\right)$ is obtained for $\mathrm{Fe}_{2} \mathrm{O}_{3} / \mathrm{Al}_{2} \mathrm{O}_{3}$ reduction with methane. Furthermore, the slop of the reduction conversion $v s$. time curves is observed to be altered for experiments conducted at the various operating temperature, which may be also attributed to the decay constant $\left(k_{\mathrm{d}}\right)$ is dependent on the operating temperatures, similar to the results reported by previous researchers. ${ }^{23,24}$ For experiments conducted with operating temperature of $900{ }^{\circ} \mathrm{C}$, the slop of the reduction conversion vs. time curves for $\mathrm{Fe}_{2} \mathrm{O}_{3} / \mathrm{Al}_{2} \mathrm{O}_{3}$ reduction is significantly changed with inlet methane concentration ranged from 5 to $20 \%$, as shown in Fig. 4 , possibly due to high $k_{\mathrm{d}, 0}$ is obtained for $\mathrm{Fe}_{2} \mathrm{O}_{3} / \mathrm{Al}_{2} \mathrm{O}_{3}$ reduction with $\mathrm{CH}_{4} .^{22}$

In this study, the gas-film diffusion and the product layer diffusion were major reaction resistances contributed for $\mathrm{Fe}_{2} \mathrm{O}_{3} /$ $\mathrm{Al}_{2} \mathrm{O}_{3}$ and $\mathrm{Fe}_{2} \mathrm{O}_{3} / \mathrm{Al}_{2} \mathrm{O}_{3} / \mathrm{TiO}_{2}$ reduction with methane in the fixed bed reactor. Cabello et al. ${ }^{22}$ studied that the kinetic study of $20 \mathrm{wt} \% \mathrm{Fe}_{2} \mathrm{O}_{3} / \mathrm{Al}_{2} \mathrm{O}_{3}$ oxygen carrier for gaseous fuel combustion by chemical looping process, and also indicated that the reduction reactions are controlled by the chemical reaction in the grain surface and the diffusion through the product layer of $\mathrm{FeAl}_{2} \mathrm{O}_{4}$ around the grains. This can be attributed to the external diffusion resistance is eliminated by using a small mass of solid sample $(50 \mathrm{mg}){ }^{22}$ Comparing the results from the literature and this study, methane more easily diffusion through the product layer of $20 \mathrm{wt} \% \quad \mathrm{Fe}_{2} \mathrm{O}_{3} / \mathrm{Al}_{2} \mathrm{O}_{3}$ oxygen carriers, while less temperature effect on the reduction conversion was observed for experiments with both iron-based oxygen carriers. The reason is due to the $D_{\mathrm{pl}, 0}$ and $E_{\mathrm{pl}}$ obtained here were significantly lower than that found in the literature. ${ }^{22}$ Additionally, the

Table 2 Kinetics parameters for the reduction of iron-based oxygen carriers conducted with methane

\begin{tabular}{llll}
\hline Parameter & Unit & $\mathrm{Fe}_{2} \mathrm{O}_{3} / \mathrm{Al}_{2} \mathrm{O}_{3}$ & $\mathrm{Fe}_{2} \mathrm{O}_{3} / \mathrm{Al}_{2} \mathrm{O}_{3} / \mathrm{TiO}_{2}$ \\
\hline$k_{\mathrm{g}}$ & $\mathrm{mm} \mathrm{s}^{-1}$ & 0.07 & 0.12 \\
$D_{\mathrm{pl}, 0}$ & $\mathrm{~mm}^{2} \mathrm{~s}^{-1}$ & $4.37 \times 10^{20}$ & $1.03 \times 10^{21}$ \\
$\mathrm{Ea}_{\mathrm{pl}}$ & $\mathrm{kJ} \mathrm{mol}^{-1}$ & 476.45 & 446.61 \\
$k_{\mathrm{d}, 0}$ & - & $3.08 \times 10^{32}$ & $7.88 \times 10^{13}$ \\
$\mathrm{Ea}_{\mathrm{d}}$ & $\mathrm{kJ} \mathrm{mol}^{-1}$ & 736.19 & 305.41
\end{tabular}

intensity of the reaction rate for reduction of both iron-based oxygen carriers with methane was significantly changed with various methane concentration probably due to higher $k_{\mathrm{d}, 0}$ and higher $E_{\mathrm{d}}$ were obtained in this work.

\subsection{Methane combustion with $\mathrm{Fe}_{2} \mathrm{O}_{3} / \mathrm{Al}_{2} \mathrm{O}_{3}$ oxygen carriers in the ADMBR}

Chemical looping combustion of methane was conducted in the ADMBR at $900{ }^{\circ} \mathrm{C}$ by feeding $\mathrm{Fe}_{2} \mathrm{O}_{3} / \mathrm{Al}_{2} \mathrm{O}_{3}$ oxygen carriers at flow rate of $29.53 \mathrm{~g} \mathrm{~min}^{-1}$ and $\mathrm{CH}_{4}$ at flow rate from 328.4 to 985.3 $\mathrm{mg} \min ^{-1}$. The main components of outlet streams for the combustion of methane from the moving bed reactor operated at different inlet $\mathrm{CH}_{4}$ flow rates were determined to be $\mathrm{CO}_{2}$, $\mathrm{CH}_{4}, \mathrm{H}_{2}$ and slightly $\mathrm{CO}$ in this study, as illustrated in Fig. 5. Outlet gas stream containing about $96 \% \mathrm{CO}_{2}$ and $4 \% \mathrm{CH}_{4}$ are achieved for experiments conducted with $\mathrm{CH}_{4} / \mathrm{Fe}_{2} \mathrm{O}_{3}$ ratio ranged from 18.5 to $37.1 \mathrm{mg} \mathrm{g}^{-1}$. However, $\mathrm{CO}_{2}$ concentration of the outlet gas stream is rapidly reduced for experiments carried out with the $\mathrm{CH}_{4} / \mathrm{Fe}_{2} \mathrm{O}_{3}$ ratio more than $37.1 \mathrm{mg} \mathrm{g}^{-1}$. More $\mathrm{CO}$ and $\mathrm{H}_{2}$ are observed due to the occurrence of incomplete methane combustion and methane decomposition reaction, as depicted by reaction (12). ${ }^{\mathbf{1 9 , 2 0}}$ Based on carbon and hydrogen balance calculation, the steam generation rate $\left(F_{\mathrm{H}_{2} \mathrm{O}}\right)$ and carbon deposition rate $\left(F_{\mathrm{C}}\right)$ for methane combustion are determined by eqn (5) and (13) and were also shown in Fig. 5.

$$
\begin{gathered}
\mathrm{CH}_{4} \rightarrow \mathrm{C}+2 \mathrm{H}_{2} \\
F_{\mathrm{C}}=F_{\mathrm{CH}_{4}, \text { in }}-\left(F_{\mathrm{CH}_{4}}+F_{\mathrm{CO}_{2}}+F_{\mathrm{CO}}\right)
\end{gathered}
$$

The carbon deposition rate and steam generation rate of methane combustion by $\mathrm{Fe}_{2} \mathrm{O}_{3} / \mathrm{Al}_{2} \mathrm{O}_{3}$ in the ADMBR are found to be increased for experiments conducted with greater $\mathrm{CH}_{4} /$ $\mathrm{Fe}_{2} \mathrm{O}_{3}$ ratio. The increased in carbon deposition for experiments carried out at high $\mathrm{CH}_{4} / \mathrm{Fe}_{2} \mathrm{O}_{3}$ ratio may be ascribed to the presence of excessive methane, thus more methane molecules are decomposed to generate carbon and hydrogen. $\mathrm{CO}_{2}$ concentrations for $\mathrm{CH}_{4}$ combustion conducted with $\mathrm{CH}_{4} / \mathrm{Fe}_{2} \mathrm{O}_{3}$

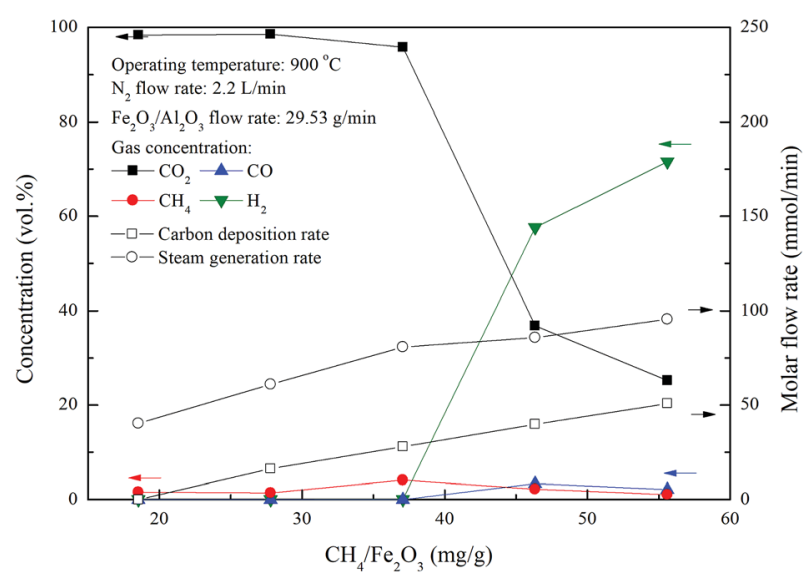

Fig. 5 Effect of methane flow rates on the combustion of methane with $\mathrm{Fe}_{2} \mathrm{O}_{3} / \mathrm{Al}_{2} \mathrm{O}_{3}$ in the moving bed. 
ratio of 27.8 and $37.1 \mathrm{mg} \mathrm{g}^{-1}$ were determined to be about $98 \%$ and $96 \%$, respectively, indicating that hydrogen generated by methane decomposition was completely combusted by $\mathrm{Fe}_{2} \mathrm{O}_{3} /$ $\mathrm{Al}_{2} \mathrm{O}_{3}$. Moreover, hydrogen was detected in the outlet stream for experiments operated at $\mathrm{CH}_{4} / \mathrm{Fe}_{2} \mathrm{O}_{3}$ ratio more than $37.1 \mathrm{mg}$ $\mathrm{g}^{-1}$, possibly due to more hydrogen generated by methane decomposition was higher than that consumed by $\mathrm{Fe}_{2} \mathrm{O}_{3} / \mathrm{Al}_{2} \mathrm{O}_{3}$ reduction reaction.

The carbonaceous gases $\left(\mathrm{CO}_{2}, \mathrm{CO}\right.$ and $\left.\mathrm{CH}_{4}\right)$ and deposited carbon are generated by methane combustion and decomposition. Therefore, carbon conversion $\left(X_{\mathrm{C}}\right)$ is the conversion of inlet methane to carbonaceous gases in the fuel reactor, as described as eqn (14). Based on the oxygen balance, the methane conversion $\left(X_{\text {methane }}\right)$ and oxygen carrier conversion $\left(X_{\mathrm{OC}}\right)$ for $\mathrm{CH}_{4}$ combustion were determined by eqn (15) and $(16) .{ }^{25,26}$

$$
\begin{gathered}
X_{\mathrm{C}}=\frac{F_{\mathrm{CO}_{2}}+F_{\mathrm{CO}}+F_{\mathrm{H}_{2} \mathrm{O}}}{F_{\mathrm{CH}_{4, \text { in }}}} \\
X_{\text {methane }}=\frac{2 F_{\mathrm{CO}_{2}}+F_{\mathrm{CO}}+F_{\mathrm{H}_{2} \mathrm{O}}}{4 F_{\mathrm{CH}_{4, \text { in }}}} \\
X_{\mathrm{OC}}=\frac{2 F_{\mathrm{CO}_{2}}+F_{\mathrm{CO}}+F_{\mathrm{H}_{2} \mathrm{O}}}{\left(\frac{x_{\mathrm{Fe}_{2} \mathrm{O}_{3}} \dot{m}_{\mathrm{OC}}}{M_{\mathrm{Fe}_{2} \mathrm{O}_{3}}}\right) \times 1000 \times 3}
\end{gathered}
$$

where $\dot{m}_{\text {OC }}$ is the mass flow rate $\left(\mathrm{g} \mathrm{min}^{-1}\right)$ of the oxygen carriers in the ADMBR. As illustrated in Fig. $6, X_{\mathrm{C}}$ and $X_{\text {methane }}$ are significantly decreased for experiments carried out with increasing $\mathrm{CH}_{4} / \mathrm{Fe}_{2} \mathrm{O}_{3}$ ratio for the combustion of methane with $\mathrm{Fe}_{2} \mathrm{O}_{3} / \mathrm{Al}_{2} \mathrm{O}_{3}$ oxygen carriers in the ADMBR operated at $900{ }^{\circ} \mathrm{C}$, indicating excessive methane is provided. Experimental results obtained in this study suggest that the complete combustion reaction between $\mathrm{CH}_{4}$ and $\mathrm{Fe}_{2} \mathrm{O}_{3} / \mathrm{Al}_{2} \mathrm{O}_{3}$ oxygen carriers could be accomplished for experiment conducted with $\mathrm{CH}_{4} / \mathrm{Fe}_{2} \mathrm{O}_{3}$ ratio of $18.5 \mathrm{mg} \mathrm{g}^{-1}$. As also indicated in Fig. 6, nearly $24.2 \%$ of the oxygen carrier conversion is achieved for the complete

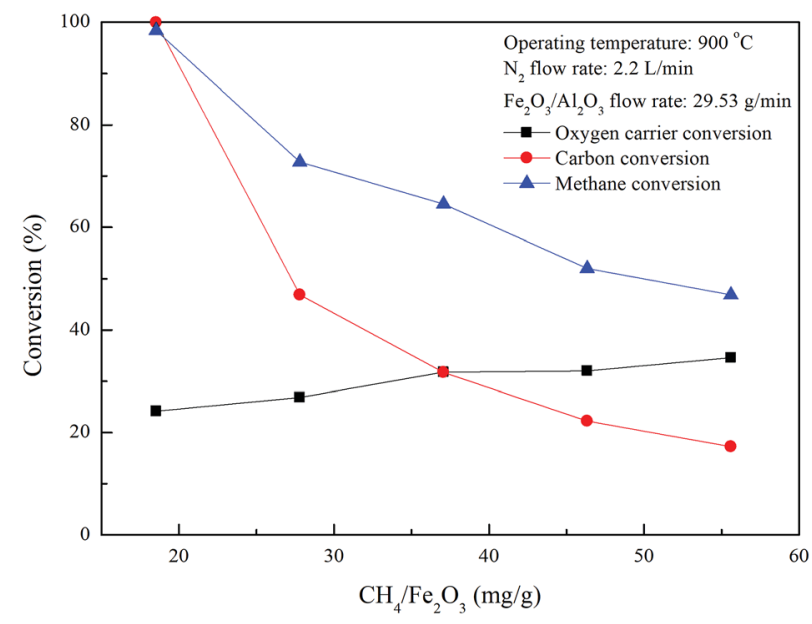

Fig. 6 Effect of methane flow rates on fuel and oxygen carrier conversions for $\mathrm{CLC}$ of methane with $\mathrm{Fe}_{2} \mathrm{O}_{3} / \mathrm{Al}_{2} \mathrm{O}_{3}$. combustion of methane with $\mathrm{Fe}_{2} \mathrm{O}_{3} / \mathrm{Al}_{2} \mathrm{O}_{3}$ oxygen carriers, demonstrating the $\mathrm{Fe}_{2} \mathrm{O}_{3} / \mathrm{Al}_{2} \mathrm{O}_{3}$ oxygen carriers operated in a moving bed reactor is majorly reduced to $\mathrm{Fe}_{3} \mathrm{O}_{4}$ and $\mathrm{FeO}$, similar to the results reported by previous study. ${ }^{27}$ However, oxygen carrier conversion for CLC of methane is found to be slightly enhanced for experiments conducted with greater $\mathrm{CH}_{4} /$ $\mathrm{Fe}_{2} \mathrm{O}_{3}$ ratio, because more $\mathrm{Fe}_{2} \mathrm{O}_{3} / \mathrm{Al}_{2} \mathrm{O}_{3}$ oxygen carriers are considered to be reduced by fuel gases, such as $\mathrm{CH}_{4}, \mathrm{CO}$ and $\mathrm{H}_{2}$, which is generated by methane combustion and decomposition.

\subsection{Methane combustion with $\mathrm{Fe}_{2} \mathrm{O}_{3} / \mathrm{Al}_{2} \mathrm{O}_{3} / \mathrm{TiO}_{2}$ oxygen carriers in the ADMBR}

Chemical looping combustion of methane by $\mathrm{Fe}_{2} \mathrm{O}_{3} / \mathrm{Al}_{2} \mathrm{O}_{3} / \mathrm{TiO}_{2}$ oxygen carriers for experiments conducted with various $\mathrm{CH}_{4} /$ $\mathrm{Fe}_{2} \mathrm{O}_{3}$ ratio were examined in this study. The outlet gas streams for combustion experiments of methane were composed mainly of $\mathrm{CO}_{2}, \mathrm{CH}_{4}, \mathrm{H}_{2}$ and $\mathrm{CO}$, as illustrated in Fig. 7. Outlet gas stream of nearly $100 \% \mathrm{CO}_{2}$ is achieved for experiments conducted with $\mathrm{CH}_{4} / \mathrm{Fe}_{2} \mathrm{O}_{3}$ ratio of $22.6 \mathrm{mg} \mathrm{g}{ }^{-1}$. However, $\mathrm{CO}_{2}$ concentration of the outlet gas stream for CLC of methane are found to be decreased for experiments carried out with $\mathrm{CH}_{4} /$ $\mathrm{Fe}_{2} \mathrm{O}_{3}$ ratio more than $34.0 \mathrm{mg} \mathrm{g}^{-1}$, whereas $\mathrm{H}_{2}$ and $\mathrm{CO}$ concentrations are increased. Besides, methane concentration of the outlet gas stream for methane combustion with $\mathrm{Fe}_{2} \mathrm{O}_{3}$ / $\mathrm{Al}_{2} \mathrm{O}_{3} / \mathrm{TiO}_{2}$ is enhanced for experiments conducted with $\mathrm{CH}_{4} /$ $\mathrm{Fe}_{2} \mathrm{O}_{3}$ ratio ranged from 34.0 to $45.3 \mathrm{mg} \mathrm{g}^{-1}$. Subsequently, $\mathrm{CH}_{4}$ concentration of the outlet gas stream is reduced for experiments conducted with $\mathrm{CH}_{4} / \mathrm{Fe}_{2} \mathrm{O}_{3}$ ratio above $45.3 \mathrm{mg} \mathrm{g}{ }^{-1}$, possibly due to the occurrence of methane reforming reaction, as depicted by reaction (17). ${ }^{28,29}$ Thus, less steam generation rate is observed for the combustion of methane with $\mathrm{Fe}_{2} \mathrm{O}_{3} / \mathrm{Al}_{2} \mathrm{O}_{3} /$ $\mathrm{TiO}_{2}$ than that for methane combustion with $\mathrm{Fe}_{2} \mathrm{O}_{3} / \mathrm{Al}_{2} \mathrm{O}_{3}$, as illustrated in Fig. 7.

$$
\mathrm{CH}_{4}+\mathrm{H}_{2} \mathrm{O} \rightarrow \mathrm{CO}+3 \mathrm{H}_{2}
$$

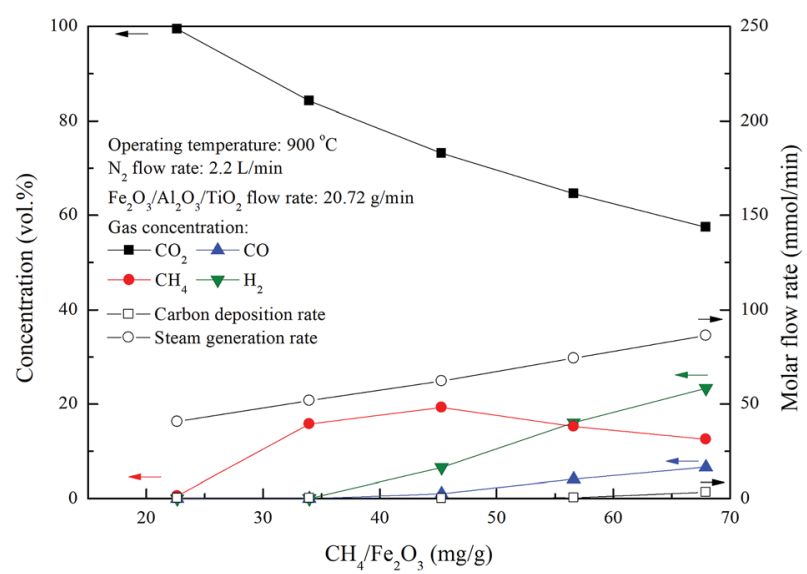

Fig. 7 Effect of methane flow rates on the combustion of methane with $\mathrm{Fe}_{2} \mathrm{O}_{3} / \mathrm{Al}_{2} \mathrm{O}_{3} / \mathrm{TiO}_{2}$ in the moving bed. 


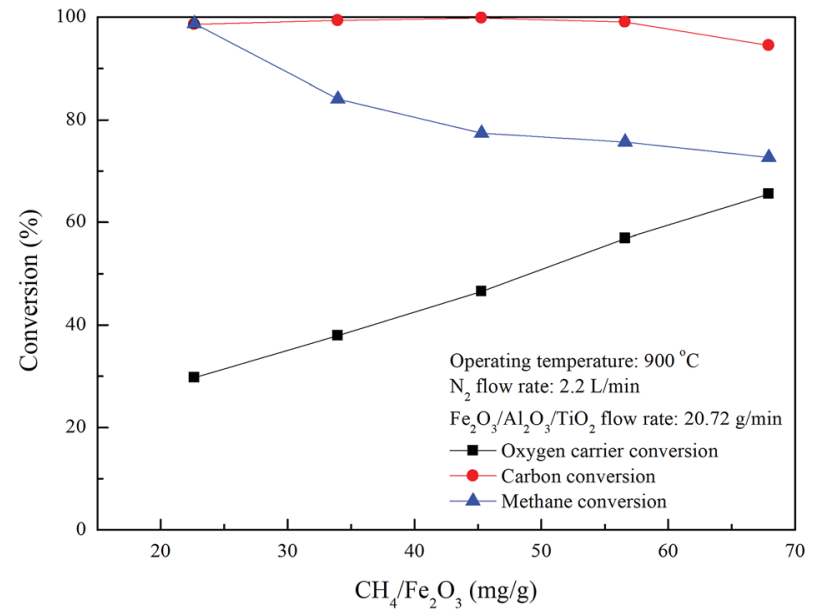

Fig. 8 Effect of methane flow rates on fuel and oxygen carrier conversions for $\mathrm{CLC}$ of methane with $\mathrm{Fe}_{2} \mathrm{O}_{3} / \mathrm{Al}_{2} \mathrm{O}_{3} / \mathrm{TiO}_{2}$.

As shown in Fig. 5 and 7, the carbon deposition rate for methane combustion with $\mathrm{Fe}_{2} \mathrm{O}_{3} / \mathrm{Al}_{2} \mathrm{O}_{3} / \mathrm{TiO}_{2}$ is noticeably lower than that for methane combustion with $\mathrm{Fe}_{2} \mathrm{O}_{3} / \mathrm{Al}_{2} \mathrm{O}_{3}$, indicating carbon deposition is significantly reduced as methane is combusted with $\mathrm{Fe}_{2} \mathrm{O}_{3} / \mathrm{Al}_{2} \mathrm{O}_{3} / \mathrm{TiO}_{2}$ oxygen carriers. Carbon deposition is impeded because the reactivity of $\mathrm{Fe}_{2} \mathrm{O}_{3} / \mathrm{Al}_{2} \mathrm{O}_{3} / \mathrm{TiO}_{2}$ oxygen carriers for methane combustion is higher than that of $\mathrm{Fe}_{2} \mathrm{O}_{3} / \mathrm{Al}_{2} \mathrm{O}_{3}$ oxygen carriers. Fig. 8 demonstrates that high carbon conversions (approximately 99\%) are obtained for methane combustion conducted with $\mathrm{CH}_{4} / \mathrm{Fe}_{2} \mathrm{O}_{3}$ ratio ranged from 22.6 to $56.6 \mathrm{mg} \mathrm{g}^{-1}$, while the carbon conversion of methane combustion reached about $94.5 \%$ for experiments carried out with $\mathrm{CH}_{4} / \mathrm{Fe}_{2} \mathrm{O}_{3}$ ratio of $67.9 \mathrm{mg} \mathrm{g}^{-1}$, due to the insufficient oxygen carriers are provided to react with methane. Thus, methane molecules are slightly decomposed to generate carbon and hydrogen. As also illustrated in Fig. 8, methane is completely combusted by $\mathrm{Fe}_{2} \mathrm{O}_{3} / \mathrm{Al}_{2} \mathrm{O}_{3} / \mathrm{TiO}_{2}$ oxygen carriers for experiment conducted with $\mathrm{CH}_{4} / \mathrm{Fe}_{2} \mathrm{O}_{3}$ ratio of $22.6 \mathrm{mg} \mathrm{g}{ }^{-1}$. However, as for experiment conducted with $\mathrm{CH}_{4} / \mathrm{Fe}_{2} \mathrm{O}_{3}$ ratio more than $22.6 \mathrm{mg} \mathrm{g}^{-1}$, the methane conversions are found to be decreased with increased with increasing $\mathrm{CH}_{4} / \mathrm{Fe}_{2} \mathrm{O}_{3}$ ratio. The decreased in methane conversion for experiments carried out at high $\mathrm{CH}_{4} / \mathrm{Fe}_{2} \mathrm{O}_{3}$ ratio may be ascribed to the occurrence of incomplete methane combustion and methane reforming reaction, thus more combustible gases are observed.
Oxygen carrier conversion of around $29.7 \%$ is achieved for the complete combustion of methane with $\mathrm{Fe}_{2} \mathrm{O}_{3} / \mathrm{Al}_{2} \mathrm{O}_{3} / \mathrm{TiO}_{2}$ oxygen carrier, while the oxygen carrier conversions are enhanced for experiment conducted with $\mathrm{CH}_{4} / \mathrm{Fe}_{2} \mathrm{O}_{3}$ ratio above $22.6 \mathrm{mg} \mathrm{g}^{-1}$, as shown in Fig. 8, further demonstrating increased $\mathrm{CH}_{4} / \mathrm{Fe}_{2} \mathrm{O}_{3}$ ratio to promote the $\mathrm{Fe}_{2} \mathrm{O}_{3} / \mathrm{Al}_{2} \mathrm{O}_{3} / \mathrm{TiO}_{2}$ reduction. Besides, $\mathrm{Fe}_{2} \mathrm{O}_{3} / \mathrm{Al}_{2} \mathrm{O}_{3}$ flowrate of around 29.53 $\mathrm{g} \mathrm{min}^{-1}$ was provided for complete methane combustion, while the $\mathrm{Fe}_{2} \mathrm{O}_{3} / \mathrm{Al}_{2} \mathrm{O}_{3} / \mathrm{TiO}_{2}$ flow rate needed to about $20.72 \mathrm{~g} \mathrm{\textrm {min } ^ { - 1 }}$ for the complete combustion of methane. Less oxygen carrier is demanded for the complete combustion of methane with $\mathrm{Fe}_{2} \mathrm{O}_{3} / \mathrm{Al}_{2} \mathrm{O}_{3} / \mathrm{TiO}_{2}$ than that for methane combustion with $\mathrm{Fe}_{2} \mathrm{O}_{3} / \mathrm{Al}_{2} \mathrm{O}_{3}$, possibly due to the methane is considered to be consumed more rapidly by $\mathrm{Fe}_{2} \mathrm{O}_{3} / \mathrm{Al}_{2} \mathrm{O}_{3} / \mathrm{TiO}_{2}$ reduction reaction than by $\mathrm{Fe}_{2} \mathrm{O}_{3} / \mathrm{Al}_{2} \mathrm{O}_{3}$ reduction reaction. Moreover, less oxygen carriers are required may also be ascribed to the higher $\mathrm{Fe}_{2} \mathrm{O}_{3}$ contained in the $\mathrm{Fe}_{2} \mathrm{O}_{3} / \mathrm{Al}_{2} \mathrm{O}_{3} / \mathrm{TiO}_{2}$ oxygen carrier. Abad et al. ${ }^{21}$ analyzed the design criteria for a CLC system and reported that the solid circulation rate was decreased with increasing the et al. oxide content for the combustion of fuel gases $\left(\mathrm{H}_{2}, \mathrm{CO}\right.$ and $\mathrm{CH}_{4}$ ) with different metal oxides ( $\mathrm{CuO}, \mathrm{NiO}$, and $\left.\mathrm{Fe}_{2} \mathrm{O}_{3}\right)$.

As listed in Table 3, the gas hourly space velocity (GHSV) of $\mathrm{CH}_{4} / \mathrm{N}_{2}$ mixture was increased with increasing inlet methane concentration. Higher GHSV means higher fuel/oxygen carrier ratios and shorter residence time. Therefore, the increase in the GHSV led to a decrease of methane and carbon conversion, whereas an increase of oxygen carrier conversion.

\subsection{Performance evaluation and heat analysis for $\mathrm{CH}_{4}$ combustion}

In order to differentiate the theoretical and actual $\mathrm{Fe}_{2} \mathrm{O}_{3}$ amount for the combustion of one mole of methane, a $\mathrm{Fe}_{2} \mathrm{O}_{3}$ / $\mathrm{CH}_{4}$ molar ratio was determined for evaluating the demand of oxygen carrier. For moving bed operation, a five-stage RGibbs reactor model has been shown to accurately simulate the experimental results for syngas and natural gas conversion. ${ }^{\mathbf{3 0 , 3 1}}$ The parameters for the ASPEN Plus ${ }^{\circledR}$ model have been proposed by Li et $a l .{ }^{18}$ and Kathe et $a l .{ }^{32}$ The maximum fuel and oxygen carrier conversions for chemical looping combustion of methane with $\mathrm{Fe}_{2} \mathrm{O}_{3}$ in the counter-current moving bed reducer operated at $900{ }^{\circ} \mathrm{C}$ and 1 atm could be obtained from ASPEN simulation under the thermodynamic equilibrium. Based on the stoichiometry calculation, 4/3 mole of $\mathrm{Fe}_{2} \mathrm{O}_{3}$ are consumed for 1 mole of methane combustion, indicating the minimum

Table 3 The operating conditions of methane combustion with iron-based oxygen carriers in the moving bed reactor ${ }^{a}$

\begin{tabular}{|c|c|c|c|c|c|c|}
\hline & $C_{\mathrm{CH}_{4}, \text { in }} \mathrm{vol} \%$ & GHSV $^{-1}$ & \multicolumn{2}{|l|}{$\mathrm{Fe}_{2} \mathrm{O}_{3} / \mathrm{Al}_{2} \mathrm{O}_{3}$} & \multicolumn{2}{|c|}{$\mathrm{Fe}_{2} \mathrm{O}_{3} / \mathrm{Al}_{2} \mathrm{O}_{3} / \mathrm{TiO}_{2}$} \\
\hline 30.7 & 25.42 & 322.4 & & 27.80 & & 33.96 \\
\hline 41 & 31.25 & 349.8 & & 37.07 & & 45.29 \\
\hline 51.2 & 36.23 & 377.1 & & 46.34 & & 56.61 \\
\hline
\end{tabular}

${ }^{a}$ GHSV: gas hourly space velocity; $F_{\mathrm{CH}_{4}, \text { in }}$ : the inlet mole flow rate of methane; $C_{\mathrm{CH}_{4} \text {, in }}$ : the inlet concentration of methane; $\dot{m}_{\mathrm{OC}}$ : the mass flow rate of the oxygen carriers in the ADMBR. 


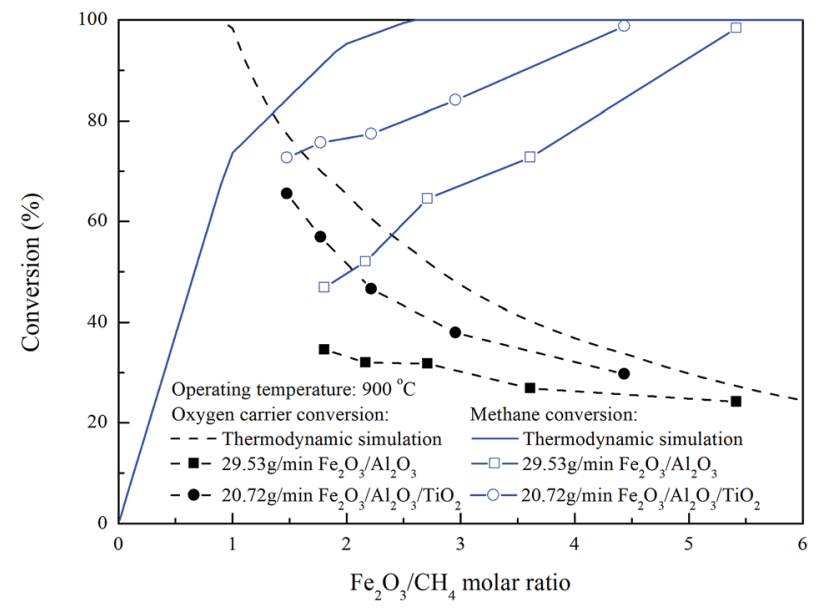

Fig. 9 Effect of $\mathrm{Fe}_{2} \mathrm{O}_{3} / \mathrm{CH}_{4}$ molar ratio on fuel and oxygen carrier conversion for methane combustion in the moving bed.

$\mathrm{Fe}_{2} \mathrm{O}_{3}$ to $\mathrm{CH}_{4}$ molar flow rate ratio is determined to be 1.33 for theoretically complete combustion of $\mathrm{CH}_{4}$. Experiments and ASPEN simulations to examine the effect of $\mathrm{Fe}_{2} \mathrm{O}_{3} / \mathrm{CH}_{4}$ molar ratio on the fuel and oxygen carrier conversions were conducted with various $\mathrm{Fe}_{2} \mathrm{O}_{3} / \mathrm{CH}_{4}$ molar ratio, and the results were shown in Fig. 9. The decrease in the oxygen carrier conversion is observed for ASPEN simulation carried out with $\mathrm{Fe}_{2} \mathrm{O}_{3} / \mathrm{CH}_{4}$ molar ratio more than 0.9 , while complete conversion of methane is achieved as $\mathrm{Fe}_{2} \mathrm{O}_{3} / \mathrm{CH}_{4}$ molar ratio reached more than 2.6, similar to the results reported by previous study. ${ }^{25,32}$ For the complete methane combustion, higher $\mathrm{Fe}_{2} \mathrm{O}_{3} / \mathrm{CH}_{4}$ molar ratio is determined by ASPEN simulation than that by stoichiometry calculation, which may be attributed to the thermodynamic resistance, hence, $\mathrm{Fe}_{2} \mathrm{O}_{3}$ is not fully reduced to Fe for the complete combustion of methane.

Compared with the simulation result, the methane conversion for the combustion of methane with $\mathrm{Fe}_{2} \mathrm{O}_{3} / \mathrm{Al}_{2} \mathrm{O}_{3}$ and $\mathrm{Fe}_{2} \mathrm{O}_{3} / \mathrm{Al}_{2} \mathrm{O}_{3} / \mathrm{TiO}_{2}$ oxygen carriers are increased for experiments conducted with higher $\mathrm{Fe}_{2} \mathrm{O}_{3} / \mathrm{CH}_{4}$ molar ratio, and reached 98.4 and $98.8 \%$ as $\mathrm{Fe}_{2} \mathrm{O}_{3} / \mathrm{CH}_{4}$ molar ratio reached 5.4 and 4.4 , as also shown in Fig. 9. More oxygen carriers are required for experiments conducted with $\mathrm{Fe}_{2} \mathrm{O}_{3} / \mathrm{Al}_{2} \mathrm{O}_{3}$ oxygen carriers than that with $\mathrm{Fe}_{2} \mathrm{O}_{3} / \mathrm{Al}_{2} \mathrm{O}_{3} / \mathrm{TiO}_{2}$ oxygen carriers, probably because lattice oxygen present in the $\mathrm{Fe}_{2} \mathrm{O}_{3} / \mathrm{Al}_{2} \mathrm{O}_{3} / \mathrm{TiO}_{2}$ oxygen carriers are more readily to react with combustible gas. Thus, the oxygen carrier conversions for the combustion of methane with $\mathrm{Fe}_{2} \mathrm{O}_{3} / \mathrm{Al}_{2} \mathrm{O}_{3} /$ $\mathrm{TiO}_{2}$ oxygen carriers are higher than that for methane combustion with $\mathrm{Fe}_{2} \mathrm{O}_{3} / \mathrm{Al}_{2} \mathrm{O}_{3}$ oxygen carriers.

According to the XRD patterns illustrated in Fig. 10, the crystalline phases of freshly prepared $\mathrm{Fe}_{2} \mathrm{O}_{3} / \mathrm{Al}_{2} \mathrm{O}_{3}$ oxygen carriers are mainly $\mathrm{Fe}_{2} \mathrm{O}_{3}$ and $\mathrm{Al}_{2} \mathrm{O}_{3}$. The oxygen carriers moved through the ADMBR was also sampled, and characterized to be mostly $\mathrm{Al}_{2} \mathrm{FeO}_{4}$, indicating that the amount of oxygen utilization from $\mathrm{F}_{2} \mathrm{O}_{3}$ to $\mathrm{FeO}$. Similar observation was reported by previous researchers. $^{20,33}$ It has been reported that the crystal phase of $\mathrm{Fe}_{3} \mathrm{C}$ might be formation during ASPEN simulation of chemical looping combustion of methane. ${ }^{25}$ The formations of $\mathrm{Fe}_{3} \mathrm{C}$ and Fe were observed for experiment conducted with $\mathrm{CH}_{4} / \mathrm{Fe}_{2} \mathrm{O}_{3}$ ratio of $55.6 \mathrm{mg} \mathrm{g}^{-1}$ and $\mathrm{Fe}_{2} \mathrm{O}_{3} / \mathrm{Al}_{2} \mathrm{O}_{3}$ flow rate of $29.53 \mathrm{~g} \mathrm{~min}^{-1}$.

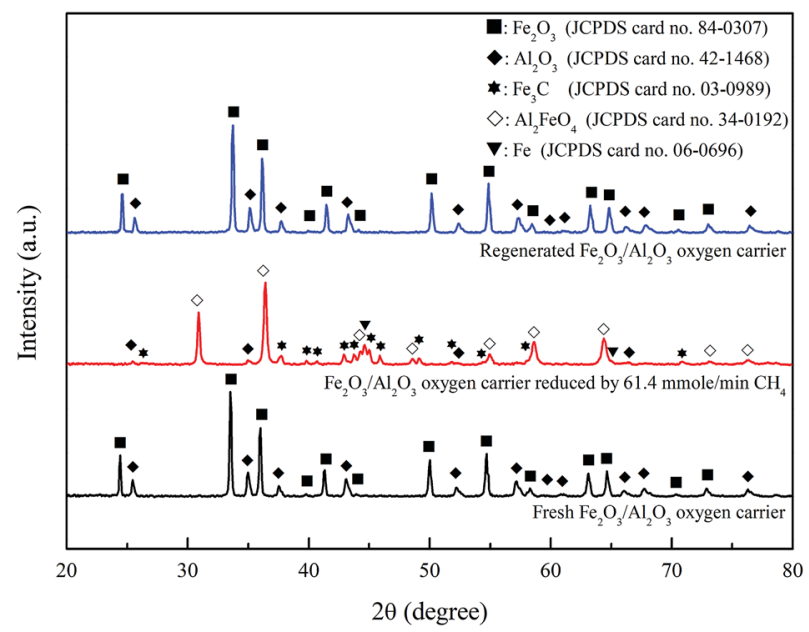

Fig. $10 \mathrm{X}$-ray diffraction patterns of fresh, reduced and regenerated $\mathrm{Fe}_{2} \mathrm{O}_{3} / \mathrm{Al}_{2} \mathrm{O}_{3}$ oxygen carriers for methane combustion.

Takenaka et $a l .{ }^{34}$ analyzed the formation of filamentous carbon over supported Fe catalysts through methane decomposition, and also reported that $\mathrm{Fe}_{3} \mathrm{C}$ formation is favored at the mass fraction of $\mathrm{Fe}_{2} \mathrm{O}_{3}$ contained in the $\mathrm{Fe}_{2} \mathrm{O}_{3} / \mathrm{Al}_{2} \mathrm{O}_{3}$ was more than $38 \%$. Additionally, $\mathrm{Fe}_{3} \mathrm{C}$ and $\mathrm{Fe}$ are the typical active species to be employed as catalyst for methane decomposition. ${ }^{34,35}$ Consequently, carbon deposition is also contributed by the $\mathrm{Fe}_{3} \mathrm{C}$ and $\mathrm{Fe}$ generated by the reaction between methane and $\mathrm{Fe}_{2} \mathrm{O}_{3} / \mathrm{Al}_{2} \mathrm{O}_{3}$ oxygen carrier. Subsequently, the reduced $\mathrm{Fe}_{2} \mathrm{O}_{3} /$ $\mathrm{Al}_{2} \mathrm{O}_{3}$ oxygen carriers are completely oxidized by air in the air reactor to generate $\mathrm{Fe}_{2} \mathrm{O}_{3}$ and $\mathrm{Al}_{2} \mathrm{O}_{3}$, which are observed in the XRD pattern.

The fresh $\mathrm{Fe}_{2} \mathrm{O}_{3} / \mathrm{Al}_{2} \mathrm{O}_{3} / \mathrm{TiO}_{2}$ particles were characterized by $\mathrm{XRD}$ for phase identification as shown in Fig. 11. $\mathrm{Fe}_{2} \mathrm{O}_{3}, \mathrm{Fe}_{2} \mathrm{TiO}_{5}$ and $\mathrm{Al}_{2} \mathrm{O}_{3}$ are the major crystalline phases of fresh oxygen carriers. For experiment conducted with $\mathrm{CH}_{4} / \mathrm{Fe}_{2} \mathrm{O}_{3}$ ratio of $67.9 \mathrm{mg} \mathrm{g}^{-1}$ and $\mathrm{Fe}_{2} \mathrm{O}_{3} / \mathrm{Al}_{2} \mathrm{O}_{3} / \mathrm{TiO}_{2}$ flow rate of $20.72 \mathrm{~g} \mathrm{~min}^{-1}$, the reduced $\mathrm{Fe}_{2} \mathrm{O}_{3} / \mathrm{Al}_{2} \mathrm{O}_{3} / \mathrm{TiO}_{2}$ oxygen carriers were sampled from moving bed operation. The absence of $\mathrm{Fe}_{2} \mathrm{O}_{3}, \mathrm{Fe}_{2} \mathrm{TiO}_{5}$ and $\mathrm{Al}_{2} \mathrm{O}_{3}$ in the XRD pattern indicated that $\mathrm{Fe}_{2} \mathrm{O}_{3}$ and $\mathrm{Fe}_{2} \mathrm{TiO}_{5}$ is completely reduced. Hence, the crystalline phases of the reduced $\mathrm{Fe}_{2} \mathrm{O}_{3} / \mathrm{Al}_{2} \mathrm{O}_{3} / \mathrm{TiO}_{2}$ oxygen carriers are composed of $\mathrm{Fe}$, $\mathrm{Fe}_{3} \mathrm{O}_{4}, \mathrm{Al}_{2} \mathrm{FeO}_{4}$ and $\mathrm{FeTiO}_{3}$, as illustrated in Fig. 11. In addition, $\mathrm{Al}_{2} \mathrm{FeO}_{4}$ and $\mathrm{FeTiO}_{3}$ generated during reduction might serve as support materials as well as oxygen carriers in practical operation by moving bed reactor for chemical looping process, similar to the results reported by previous study. ${ }^{13,36}$ For $\mathrm{Fe}_{2} \mathrm{O}_{3} /$ $\mathrm{Al}_{2} \mathrm{O}_{3} / \mathrm{TiO}_{2}$ oxygen carriers sampled after regeneration, $\mathrm{Fe}_{2} \mathrm{O}_{3}$, $\mathrm{Fe}_{2} \mathrm{TiO}_{5}$ and $\mathrm{Al}_{2} \mathrm{O}_{3}$ are observed in the XRD pattern, demonstrating that $\mathrm{Fe}, \mathrm{Fe}_{3} \mathrm{O}_{4}, \mathrm{Al}_{2} \mathrm{FeO}_{4}$ and $\mathrm{FeTiO}_{3}$ contained in the reduced $\mathrm{Fe}_{2} \mathrm{O}_{3} / \mathrm{Al}_{2} \mathrm{O}_{3} / \mathrm{TiO}_{2}$ oxygen carriers were completely oxidized to $\mathrm{Fe}_{2} \mathrm{O}_{3}, \mathrm{Fe}_{2} \mathrm{TiO}_{5}$ and $\mathrm{Al}_{2} \mathrm{O}_{3}$.

The mechanism for reduction of $\mathrm{Fe}_{2} \mathrm{O}_{3} / \mathrm{Al}_{2} \mathrm{O}_{3}$ and $\mathrm{Fe}_{2} \mathrm{O}_{3} /$ $\mathrm{Al}_{2} \mathrm{O}_{3} / \mathrm{TiO}_{2}$ oxygen carriers with methane are proposed as reactions (18)-(24) based on the experimental results from this study. Unfortunately, from the analysis of the fixed bed curves, the reduction conversion contributed by each reduction reactions were not possible to be separated because these reduction 


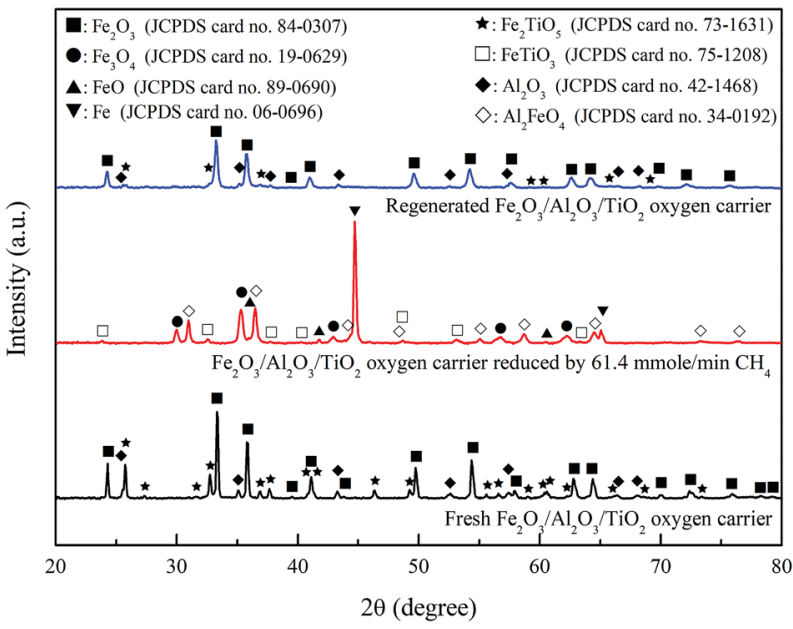

Fig. $11 \mathrm{X}$-ray diffraction patterns of fresh, reduced and regenerated $\mathrm{Fe}_{2} \mathrm{O}_{3} / \mathrm{Al}_{2} \mathrm{O}_{3} / \mathrm{TiO}_{2}$ oxygen carriers for methane combustion.

reactions may occur simultaneously. Therefore, as described by reaction (3), the overall reduction reaction of iron-based oxygen carrier for methane combustion is summarized and simplified by Integrated Rate of Reduction (IRoR) model, which has been widely used for evaluating the total reduction rate of iron ores. ${ }^{37}$

For $\mathrm{Fe}_{2} \mathrm{O}_{3} / \mathrm{Al}_{2} \mathrm{O}_{3}$ reduction:

$$
\begin{gathered}
4 \mathrm{Fe}_{2} \mathrm{O}_{3}+8 \mathrm{Al}_{2} \mathrm{O}_{3}+\mathrm{CH}_{4} \leftrightarrow 8 \mathrm{Al}_{2} \mathrm{FeO}_{4}+2 \mathrm{H}_{2} \mathrm{O}+\mathrm{CO}_{2} \\
4 \mathrm{Al}_{2} \mathrm{FeO}_{4}+\mathrm{CH}_{4} \leftrightarrow 4 \mathrm{Fe}+4 \mathrm{Al}_{2} \mathrm{O}_{3}+2 \mathrm{H}_{2} \mathrm{O}+\mathrm{CO}_{2} \\
3 \mathrm{Fe}+2 \mathrm{CO} \leftrightarrow \mathrm{Fe}_{3} \mathrm{C}+\mathrm{CO}_{2}
\end{gathered}
$$

For $\mathrm{Fe}_{2} \mathrm{O}_{3} / \mathrm{Al}_{2} \mathrm{O}_{3} / \mathrm{TiO}_{2}$ reduction:

$$
\begin{gathered}
4 \mathrm{Fe}_{2} \mathrm{O}_{3}+8 \mathrm{Al}_{2} \mathrm{O}_{3}+\mathrm{CH}_{4} \leftrightarrow 8 \mathrm{Al}_{2} \mathrm{FeO}_{4}+2 \mathrm{H}_{2} \mathrm{O}+\mathrm{CO}_{2} \\
4 \mathrm{Al}_{2} \mathrm{FeO}_{4}+\mathrm{CH}_{4} \leftrightarrow 4 \mathrm{Fe}+4 \mathrm{Al}_{2} \mathrm{O}_{3}+2 \mathrm{H}_{2} \mathrm{O}+\mathrm{CO}_{2} \\
4 \mathrm{Fe}_{2} \mathrm{TiO}_{5}+4 \mathrm{TiO}_{2}+\mathrm{CH}_{4} \leftrightarrow 8 \mathrm{FeTiO}_{3}+2 \mathrm{H}_{2} \mathrm{O}+\mathrm{CO}_{2} \\
12 \mathrm{Fe}_{2} \mathrm{O}_{3}+\mathrm{CH}_{4} \leftrightarrow 8 \mathrm{Fe}_{3} \mathrm{O}_{4}+2 \mathrm{H}_{2} \mathrm{O}+\mathrm{CO}_{2} \\
4 \mathrm{Fe}_{3} \mathrm{O}_{4}+\mathrm{CH}_{4} \leftrightarrow 12 \mathrm{FeO}+2 \mathrm{H}_{2} \mathrm{O}+\mathrm{CO}_{2} \\
4 \mathrm{FeO}+\mathrm{CH}_{4} \leftrightarrow 4 \mathrm{Fe}+2 \mathrm{H}_{2} \mathrm{O}+\mathrm{CO}_{2}
\end{gathered}
$$

The input processing capacity $\left(Q_{\text {in }}\right)$ is the enthalpy of methane calculated as:

$$
Q_{\text {in }}=\dot{m} \Delta H_{\text {Fuel }}
$$

where $\dot{m}_{\mathrm{OC}}$ and $\Delta H_{\text {Fuel }}$ are the molar flow rate $\left(\mathrm{mol} \mathrm{s}^{-1}\right)$ of methane and the higher heating value $\left(\mathrm{kJ} \mathrm{mol}^{-1}\right)$, respectively. The heat balance analysis is determined by the following equation:

$$
Q_{\text {in }}=Q_{\mathrm{C}, \text { out }}+Q_{\text {unC,out }}
$$

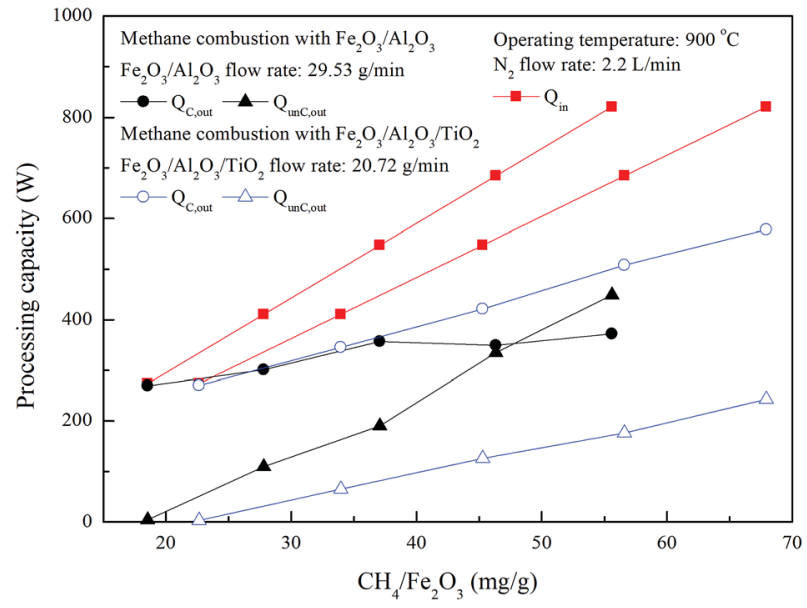

Fig. 12 Effect of methane flow rate on processing capacity for methane combustion in the moving bed.

where $Q_{\mathrm{C}, \text { out }}$ and $Q_{\mathrm{unC}, \text { out }}$ are the output processing capacity (W) for methane combustion and unburned, respectively. The output processing capacity for CLC and unburned is subsequently calculated by the following equations:

$$
\begin{gathered}
Q_{\mathrm{C}, \text { out }}=\sum\left(F_{\mathrm{j}, \text { in }}-F_{\mathrm{j}, \text { out }, \mathrm{C}}\right) \Delta H_{\mathrm{rxn}, \mathrm{j}} \\
Q_{\mathrm{unC}, \text { out }}=\sum F_{\mathrm{j}, \text { out }, \mathrm{C}} \Delta H_{\mathrm{rxn}, \mathrm{j}}
\end{gathered}
$$

where $F_{\mathrm{j}, \text { in }}$ is the inlet mole flow rate of species $\mathrm{j} ; F_{\mathrm{j}, \text { out, } \mathrm{C}}$ is the molar flow rate of species $\mathrm{j}$ generated by methane combustion; $\Delta H_{\mathrm{rxn}, \mathrm{j}}$ is the enthalpy of species $\mathrm{j}$; $\mathrm{j}$ is denoted as $\mathrm{CO}, \mathrm{CH}_{4}, \mathrm{H}_{2}$ and $\mathrm{C}$.

As shown in Fig. 12, $269 \mathrm{~W}$ and $270 \mathrm{~W}$ are released for methane combustion with $\mathrm{Fe}_{2} \mathrm{O}_{3} / \mathrm{Al}_{2} \mathrm{O}_{3}$ and $\mathrm{Fe}_{2} \mathrm{O}_{3} / \mathrm{Al}_{2} \mathrm{O}_{3} / \mathrm{TiO}_{2}$ oxygen carriers in the ADMBR, indicating that roughly $98 \%$ of $Q_{\text {in }}$ released for methane combustion using $\mathrm{Fe}_{2} \mathrm{O}_{3} / \mathrm{Al}_{2} \mathrm{O}_{3}$ and $\mathrm{Fe}_{2} \mathrm{O}_{3} / \mathrm{Al}_{2} \mathrm{O}_{3} / \mathrm{TiO}_{2}$ oxygen carriers in the ADMBR. Afterward, $Q_{\text {C,out }}$ for methane combustions with $\mathrm{Fe}_{2} \mathrm{O}_{3} / \mathrm{Al}_{2} \mathrm{O}_{3} / \mathrm{TiO}_{2}$ oxygen carriers are increased for experiments conducted with higher $\mathrm{CH}_{4} / \mathrm{Fe}_{2} \mathrm{O}_{3}$ ratio, and reached $578 \mathrm{~W}$ as methane conversion reached $72.7 \%$. However, $Q_{\mathrm{C} \text {,out }}$ for methane combustion with $\mathrm{Fe}_{2} \mathrm{O}_{3} / \mathrm{Al}_{2} \mathrm{O}_{3}$ oxygen carriers conducted with $\mathrm{CH}_{4} / \mathrm{Fe}_{2} \mathrm{O}_{3}$ ratio greater than $37.1 \mathrm{mg} \mathrm{g}^{-1}$, and reached $350 \mathrm{~W}$ as methane conversion reached less than $64.6 \%$, as shown in Fig. 12 . More heat is generated for combustion of methane by $\mathrm{Fe}_{2} \mathrm{O}_{3} / \mathrm{Al}_{2} \mathrm{O}_{3} /$ $\mathrm{TiO}_{2}$ oxygen carriers, probably because methane is more fully to react with the $\mathrm{Fe}_{2} \mathrm{O}_{3}$ contained in the $\mathrm{Fe}_{2} \mathrm{O}_{3} / \mathrm{Al}_{2} \mathrm{O}_{3} / \mathrm{TiO}_{2}$ oxygen carriers. Moreover, less heat is generated for combustion of methane by $\mathrm{Fe}_{2} \mathrm{O}_{3} / \mathrm{Al}_{2} \mathrm{O}_{3}$ oxygen carriers because more carbon deposition is formed.

\section{Conclusions}

$\mathrm{Fe}_{2} \mathrm{O}_{3}$ supported with $\mathrm{Al}_{2} \mathrm{O}_{3}$ and $\mathrm{Al}_{2} \mathrm{O}_{3} / \mathrm{TiO}_{2}$ as oxygen carrier were investigated for CLC of methane. The reduction kinetic of $\mathrm{Fe}_{2} \mathrm{O}_{3} / \mathrm{Al}_{2} \mathrm{O}_{3}$ and $\mathrm{Fe}_{2} \mathrm{O}_{3} / \mathrm{Al}_{2} \mathrm{O}_{3} / \mathrm{TiO}_{2}$ with methane are agreeably described by a shrinking core model. The results indicated that the reduction rate of $\mathrm{CH}_{4}$ for $\mathrm{Fe}_{2} \mathrm{O}_{3} / \mathrm{Al}_{2} \mathrm{O}_{3} / \mathrm{TiO}_{2}$ reduction was 
faster than that for $\mathrm{Fe}_{2} \mathrm{O}_{3} / \mathrm{Al}_{2} \mathrm{O}_{3}$ reduction, also indicated that the methane more easily diffusion through the product layer of $\mathrm{Fe}_{2} \mathrm{O}_{3} / \mathrm{Al}_{2} \mathrm{O}_{3} / \mathrm{TiO}_{2}$ oxygen carriers. The activation energy for the product layer diffusion reaction $\left(\mathrm{Ea}_{\mathrm{pl}}\right)$ estimated for CLP by employment of $\mathrm{Fe}_{2} \mathrm{O}_{3} / \mathrm{Al}_{2} \mathrm{O}_{3}$ and $\mathrm{Fe}_{2} \mathrm{O}_{3} / \mathrm{Al}_{2} \mathrm{O}_{3} / \mathrm{TiO}_{2}$ as oxygen carrier are about 476 and $447 \mathrm{~kJ} \mathrm{~mol}^{-1}$ for oxygen carrier reduction with methane, respectively. Approximately, methane is completely combusted for experiments conducted in the moving bed reactor with $\mathrm{Fe}_{2} \mathrm{O}_{3} / \mathrm{Al}_{2} \mathrm{O}_{3}$ and $\mathrm{Fe}_{2} \mathrm{O}_{3} / \mathrm{Al}_{2} \mathrm{O}_{3} / \mathrm{TiO}_{2}$ operated at $\mathrm{Fe}_{2} \mathrm{O}_{3} / \mathrm{CH}_{4}$ molar ratio reached about 5.4 and 4.4, respectively; in addition, the oxygen carrier conversions are respectively reached about $24.2 \%$ and $29.7 \%$. Carbon deposition during methane combustion is noticeably avoided by using $\mathrm{Fe}_{2} \mathrm{O}_{3} / \mathrm{Al}_{2} \mathrm{O}_{3} / \mathrm{TiO}_{2}$ as oxygen carrier. According to the XRD characterization, $\mathrm{Al}_{2} \mathrm{FeO}_{4}$ is the major crystalline phase generated during CLC of methane with $\mathrm{Fe}_{2} \mathrm{O}_{3} / \mathrm{Al}_{2} \mathrm{O}_{3}$ oxygen carrier. The formations of $\mathrm{Fe}_{3} \mathrm{C}$ and $\mathrm{Fe}$ were observed for experiment conducted with $\mathrm{CH}_{4} / \mathrm{Fe}_{2} \mathrm{O}_{3}$ ratio of $67.9 \mathrm{mg} \mathrm{g}{ }^{-1}$ and $\mathrm{Fe}_{2} \mathrm{O}_{3} / \mathrm{Al}_{2} \mathrm{O}_{3}$ flow rate of $29.53 \mathrm{~g} \mathrm{~min}{ }^{-1}$, which would serve as catalyst for methane decomposition. For $\mathrm{Fe}_{2} \mathrm{O}_{3} / \mathrm{Al}_{2} \mathrm{O}_{3} / \mathrm{TiO}_{2}$ oxygen carriers sampled after reduction, $\mathrm{Fe}, \mathrm{Fe}_{3} \mathrm{O}_{4}, \mathrm{Al}_{2} \mathrm{FeO}_{4}$ and $\mathrm{FeTiO}_{3}$ were identified by the XRD pattern, demonstrating $\mathrm{Al}_{2} \mathrm{FeO}_{4}$ and $\mathrm{FeTiO}_{3}$ generated during reduction might become support materials as well as oxygen carriers in practical operation by moving bed reactor for chemical looping process. Output processing capacity estimated for CLC by employment of $\mathrm{Fe}_{2} \mathrm{O}_{3}$ / $\mathrm{Al}_{2} \mathrm{O}_{3}$ and $\mathrm{Fe}_{2} \mathrm{O}_{3} / \mathrm{Al}_{2} \mathrm{O}_{3} / \mathrm{TiO}_{2}$ as oxygen carrier are increased for experiments conducted with higher $\mathrm{CH}_{4} / \mathrm{Fe}_{2} \mathrm{O}_{3}$ ratio, and reached $350 \mathrm{~W}$ and $578 \mathrm{~W}$ as methane conversion reached around $64.6 \%$ and $72.7 \%$, respectively. About $269 \mathrm{~W}$ and $270 \mathrm{~W}$ are released for complete methane combustion with $\mathrm{Fe}_{2} \mathrm{O}_{3}$ / $\mathrm{Al}_{2} \mathrm{O}_{3}$ and $\mathrm{Fe}_{2} \mathrm{O}_{3} / \mathrm{Al}_{2} \mathrm{O}_{3} / \mathrm{TiO}_{2}$ oxygen carriers in the ADMBR, indicating that roughly $98 \%$ of $Q_{\text {in }}$ released for methane combustion using $\mathrm{Fe}_{2} \mathrm{O}_{3} / \mathrm{Al}_{2} \mathrm{O}_{3}$ and $\mathrm{Fe}_{2} \mathrm{O}_{3} / \mathrm{Al}_{2} \mathrm{O}_{3} / \mathrm{TiO}_{2}$ oxygen carriers in the ADMBR.

\section{Conflicts of interest}

There are no conflicts to declare.

\section{Acknowledgements}

This research was supported by Grant MOST 106-3113-E-007002-from the National Science and Technology ProgramEnergy, Taiwan, and by Grant MOST 105-2622-E-011-019-CC2 and MOST 103-2221-E-011-002-MY3 from the Ministry of Science and Technology, Taiwan. The authors appreciated China Steel Corp. for providing hematite powders for the preparation of oxygen carriers.

\section{References}

1 World Energy Council (WEC), World Energy Resources Unconventional Gas, a Global Phenomenon, 2016.

2 U.S. Energy Information Administration (EIA), Annual Energy Outlook 2014 with Projections to 2040, 2014.
3 U.S. Energy Information Administration (EIA), Annual Energy Outlook 2016 with Projections to 2040, 2016.

4 L. S. Fan, Chemical Looping Systems for Fossil Energy Conversions, John Wiley \& Sons, Inc., New York, 2010.

5 J. Adánez, A. Abad, F. Garcia-Labiano, P. Gayan and L. F. de Diego, Progress in Chemical-looping Combustion and Reforming Technologies, Prog. Energy Combust. Sci., 2012, 38, 215-282.

6 J. Adánez, L. F. de Diego, F. García-Labiano, P. Gayán, A. Abad and J. M. Palacios, Selection of Oxygen Carriers for Chemical-looping Combustion, Energy Fuels, 2004, 18, 371377.

7 M. Johansson, T. Mattisson and A. Lyngfelt, Investigation of $\mathrm{Fe}_{2} \mathrm{O}_{3}$ with $\mathrm{MgAl}_{2} \mathrm{O}_{4}$ for Chemical-looping Combustion, Ind. Eng. Chem. Res., 2004, 43, 6978-6987.

8 Q. Zafar, T. Mattisson and B. Gevert, Redox Investigation of Some Oxides of Transition-state Metals $\mathrm{Ni}, \mathrm{Cu}, \mathrm{Fe}$, and Supported on $\mathrm{SiO}_{2}$ and $\mathrm{MgAl}_{2} \mathrm{O}_{4}$, Energy Fuels, 2006, 20, 33-44.

9 B. M. Corbella and J. M. Palacios, Titania-supported Iron Oxide as Oxygen Carrier for Chemical-looping Combustion of Methane, Fuel, 2007, 86, 113-122.

10 F. Li, S. Luo, Z. Sun, X. Bao and L. S. Fan, Role of Metal Oxide Support in Redox Reactions of Iron Oxide for Chemical Looping Applications: Experiments and Density Functional Theory Calculations, Energy Environ. Sci., 2011, 4, 3661-3667.

11 L. Qin, Z. Cheng, J. A. Fan, D. Kopechek, D. Xu, N. Deshpande and L. S. Fan, Nanostructure Formation Mechanism and Ion Diffusion in Iron-titanium Composite Materials with Chemical Looping Redox Reactions, J. Mater. Chem. A, 2015, 3, 11302-11312.

12 Y. Zhao and F. Shadman, Kinetics and Mechanism of Ilmenite Reduction with Carbon Monoxide, AIChE J, 1990, 36, 1433-1438.

13 P. C. Chiu, Y. Ku, Y. L. Wu, H. C. Wu, Y. L. Kuo and Y. H. Tseng, Characterization and Evaluation of Prepared $\mathrm{Fe}_{2} \mathrm{O}_{3} / \mathrm{Al}_{2} \mathrm{O}_{3}$ Oxygen Carriers for Chemical Looping Process, Aerosol Air Qual. Res., 2014, 14, 981-990.

14 M. C. Lo, Composite Fe-Ti Based Oxygen Carrier for Chemical Looping Combustion and Hydrogen Generation, Master Thesis in Department of Chemical Engineering, National Taiwan University of Science and Technology, Taipei City, Taiwan, 2014.

15 P. Markström and A. Lyngfelt, Designing and Operating a Cold-flow Model of a $100 \mathrm{~kW}$ Chemical-looping Combustor, Powder Technol., 2012, 222, 182-192.

16 Y. De Vos, M. Jacobs, P. Van Der Voort, I. Van Driessche, F. Snijkers and A. Verberckmoes, Optimization of Spray Dried Attrition-resistant Iron Based Oxygen Carriers for Chemical Looping Reforming, Chem. Eng. J., 2017, 309, 824-839.

17 R. W. Breault, C. S. Yarrington and J. M. Weber, The Effect of Thermal Treatment of Hematite Ore for Chemical Looping Combustion of Methane, J. Energy Resour. Technol., 2016, 138, 0422021-0422028.

18 F. Li, L. Zeng, L. G. Velazquez-Vargas, Z. Yoscovits and L. S. Fan, Syngas Chemical Looping Gasification Process: 
Bench-scale Studies and Reactor Simulations, AIChE J., 2010, 56, 2186-2199.

19 P. Cho, T. Mattisson and A. Lyngfelt, Carbon Formation on Nickel and Iron Oxide-containing Oxygen Carriers for Chemical-looping Combustion, Ind. Eng. Chem. Res., 2005, 44, 668-676.

20 Y. Ku, H. C. Wu, P. C. Chiu, Y. H. Tseng and Y. L. Kuo, Methane Combustion by Moving Bed Fuel Reactor with $\mathrm{Fe}_{2} \mathrm{O}_{3} / \mathrm{Al}_{2} \mathrm{O}_{3}$ Oxygen Carriers, Appl. Energy, 2014, 113, 19091915.

21 A. Abad, J. Adánez, F. García-Labiano, L. F. de Diego, P. Gayán and J. Celaya, Mapping of the Range of Operational Conditions for $\mathrm{Cu}-$, $\mathrm{Fe}-$, and Ni-based Oxygen Carriers in Chemical-looping Combustion, Chem. Eng. Sci., 2007, 65, 533-549.

22 A. Cabello, A. Abad, F. García-Labiano, P. Gayán, L. F. de Diego and J. Adánez, Kinetic Determination of a Highly Reactive Impregnated $\mathrm{Fe}_{2} \mathrm{O}_{3} / \mathrm{Al}_{2} \mathrm{O}_{3}$ Oxygen Carrier for Use in Gas-fueled Chemical Looping Combustion, Chem. Eng. J., 2014, 258, 265-280.

23 A. Abad, F. García-Labiano, P. Gayán, L. F. de Diego and J. Adánez, Redox Kinetics of $\mathrm{CaMg}_{0.1} \mathrm{Ti}_{0.125} \mathrm{Mn}_{0.775} \mathrm{O}_{2.9-\delta}$ for Chemical Looping Combustion (CLC) and Chemical Looping with Oxygen Uncoupling (CLOU), Chem. Eng. J., 2015, 269, 67-81.

24 L. F. de Diego, A. Abad, A. Cabello, P. Gayán, F. GarcíaLabiano and J. Adánez, Reduction and Oxidation Kinetics of a $\mathrm{CaMn}_{0.9} \mathrm{Mg}_{0.1} \mathrm{O}_{3-\delta}$ Oxygen Carrier for Chemicallooping Combustion, Ind. Eng. Chem. Res., 2014, 53, 87-103.

25 L. Zeng, A. Tong, M. Kathe, S. Bayham and L. S. Fan, Iron Oxide Looping for Natural Gas Conversion in a Countercurrent Moving Bed Reactor, Appl. Energy, 2015, 157, 338-347.

$26 \mathrm{H}$. C. Wu and Y. Ku, Chemical Looping Gasification of Charcoal with Iron-based Oxygen Carriers in an Annular Dual-tube Moving Bed Reactor, Aerosol Air Qual. Res., 2016, 16, 1093-1103.

27 S. Luo, S. Bayham, L. Zeng, O. McGiveron, E. Chung, A. Majumder and L. S. Fan, Conversion of Metallurgical Coke and Coal Using a Coal Direct Chemical Looping (CDCL) Moving Bed Reactor, Appl. Energy, 2014, 118, 300308.
28 P. C. Chiu and Y. Ku, Chemical Looping Process - a Novel Technology for Inherent $\mathrm{CO}_{2}$ Capture, Aerosol Air Qual. Res., 2012, 12, 1421-1432.

29 M. Kathe, C. Fryer, P. Sandvik, F. Kong, Y. Zhang, A. Empfield and L. S. Fan, Modularization Strategy for Syngas Generation in Chemical Looping Methane Reforming Systems with $\mathrm{CO}_{2}$ as Feedstock, AIChE J., 2017, 63, 3343-3360.

30 A. Tong, D. Sridhar, Z. Sun, H. R. Kim, L. Zeng, F. Wang, D. Wang, M. V. Kathe, S. Luo, Y. Sun and L. S. Fan, Continuous High Purity Hydrogen Generation from a Syngas Chemical Looping 25 kWth Sub-pilot Unit with 100\% Carbon Capture, Fuel, 2013, 103, 495-505.

31 A. Tong, L. Zeng, M. V. Kathe, D. Sridhar and L. S. Fan, Application of the Moving-bed Chemical Looping Process for High Methane Conversion, Energy Fuels, 2013, 27, 4119-4128.

32 M. V. Kathe, A. Empfield, J. Na, E. Blair and L. S. Fan, Hydrogen Production from Natural Gas Using an Ironbased Chemical Looping Technology: Thermodynamic Simulations and Process System Analysis, Appl. Energy, 2016, 165, 183-201.

33 M. Ishida, K. Takeshita, K. Suzuki and T. Ohba, Application of $\mathrm{Fe}_{2} \mathrm{O}_{3}-\mathrm{Al}_{2} \mathrm{O}_{3}$ Composite Particles as Solid Looping Material of the Chemical-loop Combustor, Energy Fuels, 2005, 19, 2514-2518.

34 S. Takenaka, M. Serizawa and K. Otsuka, Formation of Filamentous Carbons Over Supported Fe Catalysts Through Methane Decomposition, J. Catal., 2004, 222, 520-531.

35 C. Emmenegger, J. M. Bonard, P. Mauron, P. Sudan, A. Lepora, B. Grobety, A. Züttel and L. Schlapbach, Synthesis of Carbon Nanotubes Over Fe Catalyst on Aluminum and Suggested Growth Mechanism, Carbon, 2003, 41, 539-547.

36 Y. Ku, Y. C. Liu, P. C. Chiu, Y. L. Kuo and Y. H. Tseng, Mechanism of $\mathrm{Fe}_{2} \mathrm{TiO}_{5}$ as Oxygen Carrier for Chemical Looping Process and Evaluation for Hydrogen Generation, Ceram. Int., 2014, 40, 4599-4605.

37 A. Abad, J. Adánez, A. Cuadrat, F. García-Labiano, P. Gayán and L. F. de Diego, Kinetics of Redox Reactions of Ilmenite for Chemical-looping Combustion, Chem. Eng. Sci., 2011, 66, 689-702. 